\title{
Pancreatic adenocarcinoma, chronic pancreatitis, and MODY-8 diabetes: is bile salt-dependent lipase (or carboxyl ester lipase) at the crossroads of pancreatic pathologies?
}

\author{
Dominique Lombardo ${ }^{1}$, Françoise Silvy ${ }^{1}$, Isabelle Crenon ${ }^{1}$, Emmanuelle Martinez ${ }^{1}$, \\ Aurélie Collignon ${ }^{1}$, Evelyne Beraud ${ }^{1}$ and Eric Mas ${ }^{1}$ \\ ${ }^{1}$ Aix Marseille Univ, INSERM, CRO2, Centre de Recherche en Oncologie Biologique et Oncopharmacologie, Marseille, France
}

Correspondence to: Dominique Lombardo, email: Dominique.lombardo@univ-amu.fr

Keywords: pancreatic adenocarcinoma; chronic pancreatitis; diabetes; bile salt-dependent lipase; carboxyl ester lipase

Received: May 07, 2017 Accepted: November 06, $2017 \quad$ Published: December 22, 2017

Copyright: Lombardo et al. This is an open-access article distributed under the terms of the Creative Commons Attribution License 3.0 (CC BY 3.0), which permits unrestricted use, distribution, and reproduction in any medium, provided the original author and source are credited.

\section{ABSTRACT}

Pancreatic adenocarcinomas and diabetes mellitus are responsible for the deaths of around two million people each year worldwide. Patients with chronic pancreatitis do not die directly of this disease, except where the pathology is hereditary. Much current literature supports the involvement of bile salt-dependent lipase (BSDL), also known as carboxyl ester lipase (CEL), in the pathophysiology of these pancreatic diseases. The purpose of this review is to shed light on connections between chronic pancreatitis, diabetes, and pancreatic adenocarcinomas by gaining an insight into BSDL and its variants. This enzyme is normally secreted by the exocrine pancreas, and is diverted within the intestinal lumen to participate in the hydrolysis of dietary lipids. However, BSDL is also expressed by other cells and tissues, where it participates in lipid homeostasis. Variants of BSDL resulting from germline and/or somatic mutations (nucleotide insertion/deletion or nonallelic homologous recombination) are expressed in the pancreas of patients with pancreatic pathologies such as chronic pancreatitis, MODY-8, and pancreatic adenocarcinomas. We discuss the possible link between the expression of BSDL variants and these dramatic pancreatic pathologies, putting forward the suggestion that BSDL and its variants are implicated in the cell lipid metabolism/reprogramming that leads to the dyslipidemia observed in chronic pancreatitis, MODY-8, and pancreatic adenocarcinomas. We also propose potential strategies for translation to therapeutic applications.

\section{INTRODUCTION}

Pancreatic adenocarcinomas (PAC) and diabetes mellitus are responsible for the deaths of around two million people each year worldwide [http://www.who. int/diabetes/global-report/en/ and http://globocan.iarc.fr]. Unlike these pancreatic diseases, chronic pancreatitis is not generally a direct cause of death; patients typically die of complications such as digestive haemorrhages, except where the chronic pancreatitis is hereditary. Pancreatic cancers represent $10 \%$ of all digestive cancers; $90 \%$ of these are PAC (GloboCan 2012, http://gco.iarc.fr/today/ home). The survival rate is extremely low, with a case fatality ratio of about 0.9 . PAC could be the second cause of death by cancer by 2030 [1], and today has a 5 -year survival rate of less than $4 \%$ in western countries [2]. Its poor prognosis is mainly due to its lack of response to currently available therapies $[3,4]$ and to a very low curative resection rate ( $15 \%$ of patients). This low curative resection rate is due to the fact that patients present with nonspecific symptoms, which, along with a lack of early biological markers, results in delayed diagnosis and metastasis formation. Risk factors for developing pancreatic cancer are multiple, and include many genetic syndromes such as Lynch syndrome and Peutz-Jeghers syndrome [5]. Chronic pancreatitis, along with longlasting type 2 diabetes mellitus (when it is itself not a consequence of pancreatic cancer [6]), may contribute to PAC development by generating oxidative stress and DNA damage [7]. Smoking, type 2 diabetes, and chronic 
pancreatitis account for one-quarter to one-third of pancreatic cancers [3]. Mass sequencing studies have so far been unsuccessful in highlighting any potential genetic etiology shared between these pancreatic pathologies.

The purpose of this review is to bring together evidence connecting these pancreatic diseases, focusing on bile salt-dependent lipase (BSDL), also known as carboxyl ester lipase [CEL, 8]. BSDL is found in the pancreatic secretions of all species examined up to now, from fish to humans [9-11]. BSDL, having broad specificity, can hydrolyze triacylglycerides, esters of cholesterol, phospholipids, esters of lipid-soluble vitamins $[12,13]$ and ceramides $[14,15]$. When it reaches the duodenal lumen, and after activation by primary bile salts, BSDL, in concert with other pancreatic lipolytic enzymes and preduodenal lipases, acts to complete the digestion of dietary lipids [12, $13,16]$. BSDL is also expressed by the lactating mammary glands of many species [17], including humans [17-21]. As an enzyme, BSDL plays an important role in milkfat digestion and absorption in suckling newborns [22]. This role is essential, as at birth the human pancreas is unable to secrete sufficient lipolytic enzymes to ensure lipid digestion [23]. In newborns, intestinal BSDL generates lipolytic products that are toxic to trophozoites such as Giardia lamblia, the cause of giardiasis and severe diarrhea and malabsorption [24]. BSDL in milk also protects the intestine from fat-derived injury [25], preventing neonatal necrotizing enterocolitis [26]. The toxicity of human milk to a number of other pathogens (Entamoeba histolytica, Trichomonas vaginalis, herpes simplex virus (type II), and Staphylococcus aureus) has been attributed to lipids following the hydrolytic activity of BSDL [27, 28]. Although BSDL was first thought to be limited to the gastrointestinal tract, it has since been detected in the plasma of patients with diabetes [29] and normolipidemic patients [30]. BSDL (mRNA or protein) is also found in testis and adrenal glands [31], endothelial cells [32], aortic homogenates [33], eosinophils and macrophages [34, 35] and pituitary glands [36, 37]. The distribution of the enzyme throughout various tissues suggests that BSDL may have multiple effects on biological functions, particularly in cell and tissue lipid metabolism. For example, in testis and adrenal glands, BSDL may participate in the homeostasis of cholesteryl esters to provide free cholesterol for the synthesis of steroids [31]. In the pituitary gland, BSDL hydrolysis of ceramides can positively regulate pituitary hormone secretion in both normal and adenomatous pituitary cells [36]. Endothelial BSDL can hydrolyze lysophospholipids, thereby inhibiting their cytotoxic effects [32]. In human eosinophils, BSDL may prevent cells from being lysed by the large amount of lysophospholipid present in the plasma membranes of parasites [34]. Both vascular and circulating as well as BSDL originating from macrophages $[33,38,39]$ may interact with lipoproteins (chylomicrons and LDL) to modulate the progression of atherosclerosis
$[32,33,35,39]$. The physiological role of the hepatic enzyme is less clear [40-42]; it may play a role in the metabolism of chylomicron remnants in the space of Disse [43]. However, the uptake of chylomicron retinyl ester by the liver and other tissues in BSDL-deficient mice generated by targeted disruption of the BSDL gene is not affected when compared to wild-type mice [44]. Bile salts particularly primary bile salts are essential to the enzyme activity on water-insoluble substrates (hence the name of the enzyme) such as cholesteryl esters [8]. However, data showed that the Platelet-Activating Factor (PAF) and (lyso) phosphatidic acid (but not (lyso)phosphatidylcholine) may also act as effective activators both on water- and lipidsoluble substrates [45]. Consequently, BSDL appears to play a role in intracellular lipid metabolism that is distinct from its action as a lipolytic digestive enzyme.

\section{Gene organization and BSDL structure}

The gene of the human BSDL is 9850 bp long. It is located at locus 9q34.3 of chromosome 9 [46], and close to the ABO locus [47]. Of the species examined to date, there is high conservation of the numbering and positioning of the intron-exon organization, and the BSDL gene consists of 11 exons [37]. Figure 1 shows the specific site or domain encoded for by each individual exon. The BSDL mRNA 5'-untranslated domain and the signal peptide are encoded by exon 1 , the least conserved of the exons. Exon 2 encodes part of the heparin-binding site [11]. The two disulfide bridges present on BSDL are encoded by exons 3 and 7 [48, 49], and help to preserve the structure of the enzyme. Exons 5, 8, and 10 encode the Ser194, Asp320, and His435 residues [50-52], respectively, which constitute the catalytic site and participate in the catalysis of water-soluble and lipid-soluble substrates [53]. Facing the active site, a short loop is formed by the first disulfide bridge between Cys64 and Cys80, [53]. This bridge might act as a pseudo-lid i.e. a nonfunctional counterpart of the lid displayed by classical triacylglycerol lipases, which is involved in interfacial activation [55] - a process not exhibited by BSDL [56]. In addition, a basic amino acid sequence, Lys61-Lys62-Arg63, is constitutive of the specific bile salt-binding site and is encoded by exon 3 [57], while a hydrophobic domain of BSDL located between Asn98 and Leu121, which could be exposed at the surface of the protein during enzyme folding [58], is encoded by exon 4 [11]. Another loop region, generated by the consensus sequence that is between Gly117 and Glu130, is also encoded by exon 4 [11]. The binding of primary bile salt to its specific [25] (or activation [59], or proximal [54]) BSDL binding site promotes the withdrawal of this loop so that the substrate can move into the active site [54]. This explains the requirement for primary bile salts for the dimerization and activation of BSDL to occur [25]. In addition, crystal studies indicate that, when bile salt molecules are not present, BSDL 
has a functional oxyanion hole and a catalytic site that is preformed [60], which explains its action on watersoluble esters in the absence of bile salts [24]. Studies using recombinant BSDL, however, have suggested that dimerization might not be required for the BSDL activation by bile salts [61]. Crystal structure analysis [54], computer modeling analysis [62], and site-directed mutagenesis [63] demonstrate that modification of BSDL enzymatic activity by micellar bile salt involves the Arg63 and Arg423 residues (which do not interact with bile salts directly) via intramolecular hydrogen bonding with the C-terminal domain of BSDL. Bile salt interaction with the lid domain would disrupt bonding, causing the loop to move away [54], and therefore pulling the C-terminal domain out of the catalytic site [63]. Exon 5 encodes a $N$-glycosylation site at Asn 187 [48] and exon 8 codes for the phosphorylation site at Thr340 [64]. Exon 9 codes for the V3-like loop involved in BSDL intracellular transport [65] and interaction with the CXCR4 chemokine receptor of platelets [66]. Exon 10 encodes a second cluster of basic residues from Arg423 to Lys462 characterized as the nonspecific (or distal) bile salt-binding site [67]. Exon 6 codes for structural domains that are well conserved during evolution i.e. helix- $\alpha \mathrm{D}$ and $\beta$-sheet-6 [37].

To conclude the gene organization schema, it should be noted that the final exon, exon 11, contains a highly polymorphic GC-rich region [17]. This exon is composed of a variable number of tandem repeated identical sequences, or VNTR and codes for the $\mathrm{C}$-terminal domain of BSDL [17, 68]. The C-terminal domain is formed of repeats of 11 amino acid units known as mucin-type PEST repeats (rich in proline, glutamic acid, serine, and threonine). There are variations in the number of tandem repeats between individuals, from three to 23 , with 16 repeats being the most common in both Asian and Caucasian populations [68-72]. The BSDL C-terminal tail of 11 amino acid residues that follows the final repeat again shows high conservation among species [11]. Importantly, each repeat carries an $O$-glycosylated structure [48]. The physiological significance of these C-terminal repeats is still unknown. Recombinant BSDL that lacks these repeats exhibits similar activity to the native enzyme, showing that the $\mathrm{C}$-terminal domain is not critical for enzymatic catalysis [70-73]. Nonetheless, the truncation by mutagenesis of the $\mathrm{C}$-terminal domain suggests the involvement of this domain in bile salt modulation of the secretion [74] and catalytic activity of BSDL [63]. Moreover, bile salt activation and enzymatic activity are not dependent on $O$-glycosylation $[71,75]$. However, the catalytic domain of BSDL is stabilized by glycosylation of the C-terminal repeated sequences [76]. In addition, glycosylation of this $\mathrm{C}$-terminal domain may protect BSDL from duodenal proteolytic degradation [76]. Exon 11 of rat $B S D L$ also codes for a sequence located before the repeats that is involved in the intracellular transport of BSDL [74]. Among species, therefore, there is high conservation of the entire amino acid sequence of the N-terminal domain [37].

In primates, there is a striking similarity between the BSDL gene and another gene $[46,77,78]$. This gene spans $4846 \mathrm{bp}$ and lacks a large $5 \mathrm{~kb}$ segment, which, when compared to the BSDL gene, includes BSDL exons $2-7$. In human, the tissue specificity of this transcribed gene, referred to as the $B S D L$ pseudogene (BSDLP) [78], has been lost during organogenesis [79]. The $B S D L$ and $B S D L P$ genes, which are found in tandem at the same locus of chromosome 9, may be the result of gene duplication. The origins of the duplication, restricted to higher primates only [77], are unknown. It is possible that a transposon-like mechanism has occurred at some stage in the replication process [46]. This process results in an additional copy of a gene being inserted upstream from the primary location, forming a lengthy duplicated sequence at the boundary of the insertion [46]. It is probable that the original gene encoding BSDL has been inactivated during evolution and become a pseudogene [80]. The inactivation of an original gene is unusual, and in the case of BSDL it is difficult to envision what was the selection pressure involved in this process, since tissue specificity and enzyme intestinal function are well conserved among species. The transposon-like mechanism hypothesis is supported by the observation that the promoter regions of the mouse gene and human pseudogene are highly similar $[46,81]$. There is no homology shared between BSDL, or its gene, and other lipases, or corresponding genes. BSDL does, however, share homology with acetylcholine esterase [17, 82], indicating the evolution of the BSDL gene as a distinct lipase/esterase gene.

\section{Gene regulation}

$B S D L$ expression is dependent on the proximal 839 bp of the 5'-flanking promoter region that encompasses the CCAAT and TATA elements [83]. Two closely located cis-elements constitute the enhancer element [84]. The proximal sub-element mediates a positive effect, whereas the distal one exerts a silencing effect on the proximal element. No homology is shared between these cis-elements and known cis-elements - the activity of the enhancer therefore appears to be dependent on currently unidentified transcription factors. Evident in the 5'-flanking region of $B S D L$, however, are consensus sequences of numerous well known transcriptional regulatory elements that respond to glucocorticoids (glucocorticoid regulatory element, GRE), sterols (sterol regulatory domain, SRD), interferon (interferon regulatory factor, IRF), and the acute-phase response element, as well as to APs and Sp1 ubiquitous transcription factor binding sites [83]. The CpG-rich islands that are frequently found in association with housekeeping gene promoter regions are not detectable in the promoter of $B S D L$ [83]. Despite 
the restriction of pancreatic $B S D L$ expression to the exocrine tissue, its regulation appears to be different from that of the elastase I gene promoter [85]. In the elastase gene, PTF-1 (pancreas specific transcription factor 1a, which plays an essential role in early and late pancreas development and differentiation) acts by binding to the A element of the gene, and restricting elastase expression to acinar cells [86]. The $B S D L$ promoter contains a putative PTF-1 binding site. However, nucleotide modifications in the human promoter 5'-flanking of this PTF-1 site create a CCAAT/enhancer-binding protein (C/EBP)-like binding motif that overlaps the p64-binding site of the PTF-1 motif [87]. Such differences result in the formation of a new exocrine-specific complex in the human BSDL gene, compensating for the fact that PTF-1 is prevented from binding to the proximal site in the human $B S D L$ promoter. Therefore, PTF-1, which participates in the regulation of elastase, $\alpha$-amylase, and colipase expression in the pancreas $[85,86,88]$, appears not to be involved in pancreatic BSDL gene activation [84, 87]. Some other putative binding sites for transcription factors along with an miRNA485-5p binding site have been identified in silico [37]. However, regulatory motifs on the BSDL gene still require characterization.

\section{Transport of BSDL in pancreatic acinar cells}

The transport of BSDL in pancreatic acinar cells occurs in close association with a folding membrane complex involving Grp94 [89]. BSDL binding to glycosphingolipids in lipid rafts by means of a V3like loop probably plays an important role in ensuring the adequate folding of the enzyme [65]. Both $N$ - and $O$-glycosylation of the protein are involved in the BSDL secretion process. In order for the enzyme to become correctly folded and fully active, transfer of the $\mathrm{N}$-oligosaccharide precursor on to the Asn 187 residue [11, $62,79,81,90-94]$ of the nascent BSDL is required [95]. This may be due to the fact that the catalytic site serine at position 194 and the $N$-glycosylation site at Asn 187 [50] are in close proximity. Once it has been transferred as a whole to the Asn187, the $N$-glycan structure can be trimmed and matured without affecting the secretion rate of the protein [95]. The non- $N$-glycosylated BSDL fraction is directed to the ubiquitin-dependent proteasome degradation pathway [96]. Ubiquitinated BSDL (UbBSDL) degradation takes place at the membrane level, with no obvious retrotranslocation to the cytosol [96]. BSDL association with the membrane is triggered by ATP [97], which translocates into the endoplasmic reticulum (ER) [98] and is critical for the degradation of BSDL [96]. It therefore appears that $N$-linked glycans are critical for BSDL transfer from the ER (where transfer of the oligomannosidic structure onto the enzyme occurs) to the cis-Golgi network. Once transferred to the cis-Golgi compartment, $O$-glycosylation of the $N$-glycosylated
BSDL occurs at the repeated C-terminal sequences (PEST sequences), mainly on residues of threonine [48]. Free PEST repeats signal the degradation of BSDL [99]. Thus, the enzyme that presents any free (i.e. non-glycosylated) PEST repeats is probably targeted for degradation. The fraction of BSDL that becomes secretion-competent upon completion of $O$-glycosylation moves to the transGolgi network. Association with intracellular membranes is required for transfer of BSDL to the trans-Golgi compartment from the ER [58, 100]. Protein casein kinase II $[97,101]$ phosphorylates the Thr340 residues of the BSDL fraction that arrives at the trans-Golgi network [64]. Thr340 phosphorylation, found in human, rat, ferret, bovine, and mouse BSDL [11], is involved in releasing BSDL from membranes [65, 97] and in allowing its movement to the secretion pathway [64, 97, 101]. Phosphorylation of the BSDL fraction that is not completely $O$-glycosylated may not occur; in fine it would be targeted towards the degradation pathway that involves the ubiquitin-dependent proteasome [96]. It should be noted that Thr340 phosphorylation is not essential for the activation by bile salts or enzyme activity [64]. Following its phosphorylation, BSDL is released from intracellular membranes. Later stages of the folding process involve membrane-associated Grp94 chaperone [102]; in the transGolgi network the chaperone probably assists in directing BSDL towards secretion [89]. The folding complex, which includes Grp94 [89], also helps to complete the $O$-glycosylation of BSDL [99] by accompanying BSDL along the secretion pathway from the ER to the Golgi [103], and by ensuring that it is kept in close contact with the membrane glycosyltransferases of the Golgi. $O$-glycosylation would not occur in BSDL molecules that Grp94 was unable to adequately accommodate and these would subsequently be targeted for degradation by the proteasome, suggesting that Grp94 could be an essential sensor in the trans-Golgi network for the correct folding of BSDL [99]. Ub-BSDL degradation could therefore either occur at the level of the trans-Golgi membranes or after a return to the ER [97]. Rab6-dependent vesicular transport may take BSDL molecules that are abnormal or incompletely $O$-glycosylated back to the ER from the Golgi [104, 105]. Therefore, two processes in pancreatic acinar cells may act as sensors of the BSDL folding stage. The first could act in the ER to separate non- $N$ glycosylated BSDL molecules. The second process could operate in the trans-Golgi compartment to sense non- $O$ glycosylated BSDL molecules. Both processes would therefore direct the abnormal BSDL molecules to the ubiquitin-dependent proteasome degradation pathway.

Essentially, phosphorylation at Thr340 [64] frees BSDL from intracellular membranes, sorting the phosphorylated secretion-competent BSDL molecules from the non-phosphorylated ones. These latter molecules are consequently secretion-incompetent and are potentially returned to the ER for more cycles of $O$-glycosylation, or 
targeted for degradation by the proteasome. Grp94, which senses the correct folding of BSDL, could be involved at this level [89]. BSDL molecules sensed as being secretioncompetent are subsequently directed to the condensing vacuoles and zymogen granules of the secretory compartment. $O$-glycosylation seems to be important not only for intracellular transport/secretion and for masking PEST sequences [8], but also for the solubility of the protein, by preventing self-association due to hydrophobic areas exposed at the surface of the enzyme [61].

Importantly, the glycosylation of BSDL differs depending on the pathophysiological status of the pancreatic acinar cells $[106,107]$. The fate of the enzyme in pathophysiological conditions that might affect its transportation in pancreatic acinar cells should therefore be examined.

\section{BSDL and pancreatic pathologies}

\section{Diabetes}

Diabetes is a chronic disease that occurs when the endocrine cells of the pancreas do not produce enough insulin, or when the organism is unable to properly use insulin to regulate blood sugar concentration. In 2012, diabetes mellitus was the direct cause of 1.5 million deaths [http://www.who.int/diabetes/global-report/en/].

Autoantibodies specifically directed towards BSDL are found in patients with diabetes. This indicates that there are certain situations in which the enzyme, or the degradation products of the enzyme, is identified as nonself [108]. The prevalence of these autoantibodies against BSDL demonstrates that the exocrine tissue of the pancreas might be affected in type 1 autoimmune diabetes at onset, and in first-degree relatives of diabetic subjects [108]. The origin of such antibodies is puzzling. The high blood glucose concentrations found in patients with diabetes and during the postprandial phase in people with prediabetes may affect the metabolism of sugars and impact the hexosamine biosynthesis pathway. The metabolism of acinar cells may also be affected by blood glucose level, as seen in human hepatoma cells [109], resulting in glycosylated entities that are immunogenic. The modification of BSDL glycosylation, in particular the $O$-glycosylation of PEST repeats, influences its intracellular transport and degradation $[71,75,99]$, and may result in antigenic glycopeptides generated by protein degradation being exposed at the surface of acinar cells and presented to the immune system. Considering that antibodies are not generated against circulating BSDL $[108,110,111]$, the membrane presentation of these antigenic glycopeptides could be essential. Both modifications of the sugar metabolism of acinar cells and membrane presentation of glycopeptides may explain the presence of autoantibodies directed against the C-terminal domain of BSDL in some patients with type 2 diabetes [108]. However, the presence of autoantibodies against BSDL in first-degree relatives without clinical diagnosis suggests the involvement of genetic factors [108].

Circulating antibodies to BSDL are also detected in an autosomal dominant inherited syndrome of exocrine

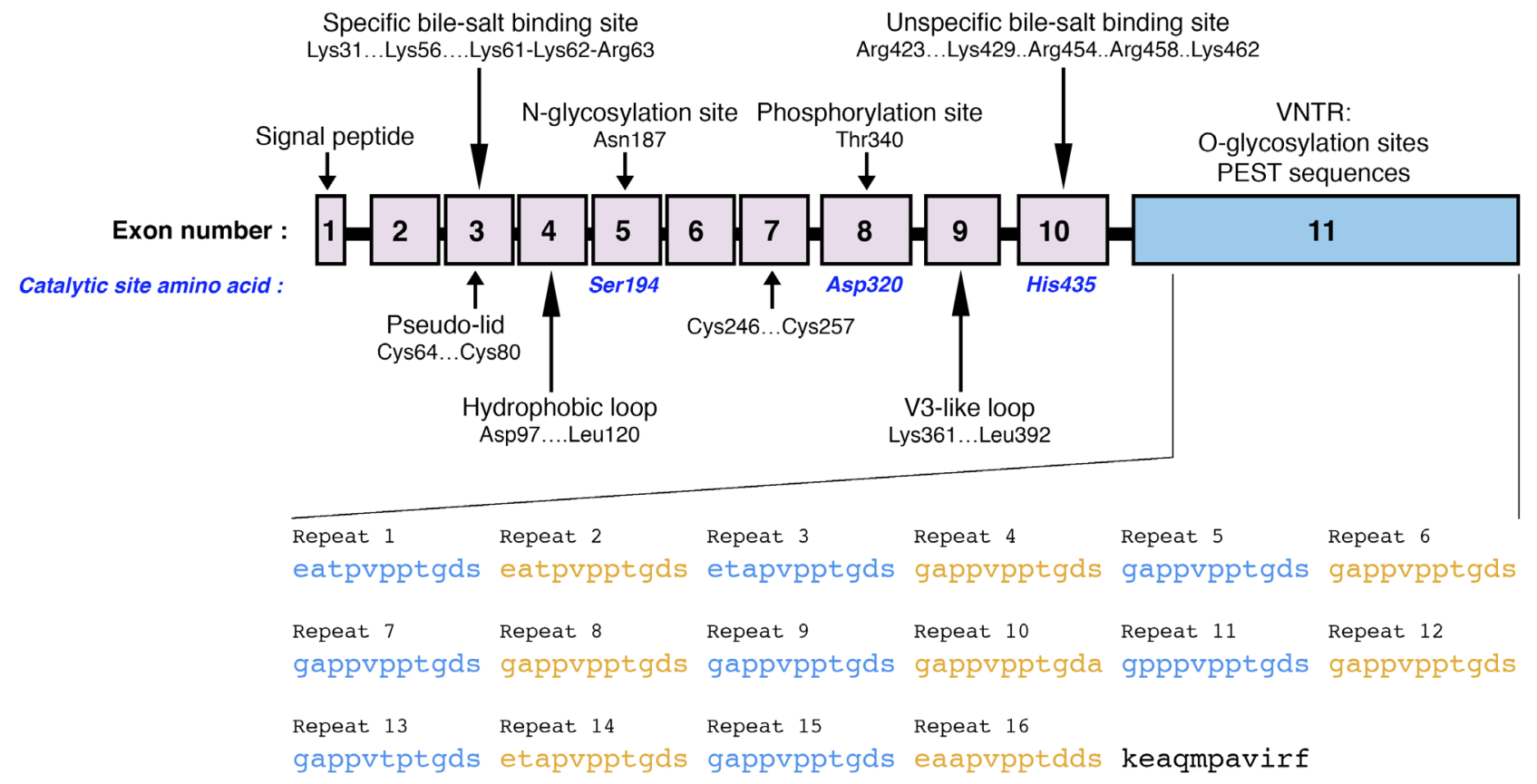

Figure 1: Schematic representation of the BSDL gene coding sequence. Numbered boxes represent each exon of the gene. Arrows show the sequence areas that code for specific structures or sites of the protein. The amino acids involved in the catalytic site of BSDL are indicated in blue. VNTR sequences encoded by exon 11 (blue box) are displayed as full amino acid sequences. 
dysfunction and diabetes (personal observation). This syndrome, now referred to as MODY-8 (maturity-onset diabetes of the young, type 8 ), is due to a single-base deletion mutation in the BSDL VNTR (c.1686delT or c.1785delC) (Figure 2) detected in two independent Norwegian families [112]. This syndrome affects both acinar and beta pancreatic cells [112]. Fat deposition (lipomatosis) is observed in the pancreas of the mutation carriers before the disease is diagnosed [113]. This pathogenic process, associated with the expression of mutated BSDL and an upregulation of mitogen-activated protein kinase signaling [114], takes place in the exocrine pancreas early in infancy, ultimately leading to diabetes when people reach their forties. The c.1686delT mutation appearing in the first VNTR of the $B S D L$ leads to a frameshift, and consequently to modification of the C-terminal domain of the protein (referred to as CELMUT) [112]. Norwegian studies further show that CELMUT and wild-type BSDL display post-translational modifications and similar rates of secretion. However, CEL-MUT is misfolded and is prone to form aggregates leading to activation of the unfolded protein response (UPR) in a HEK293 cell model transfected with the cDNA encoding CEL-MUT $[115,116]$. Once secreted, CEL-MUT lines the outside plasma membranes. The aggregated protein undergoes a robust reuptake, which occurs after secretion. This reuptake, by both exocrine and endocrine cells, is followed by transport to the lysosome where the protein is degraded. Furthermore, the viability of both acinar and beta cells is affected upon capture of aggregates [117]. This leads a mixed distribution of the protein in cells, with mutated BSDL present in secretory pathway vesicles (BSDL associated with Grp94) and in vesicles of the endocytic pathway (BSDL in early endosomes and lysosomes) [117]. Torsvik et al. [117] reported that CEL-MUT was not degraded via the autophagosomal pathway. The absence of autophagy suggests that aggregates do not form during CEL-MUT synthesis but rather after its release outside the acinar cell. Once reuptaken, the protein is transported to the lysosome degrading compartment [117]. Consequently, CEL-MUT affects the viability of both acinar and beta cells, providing a possible (albeit simplistic) explanation of the specific symptoms of this pathology [116, 117]. Studies show that CEL-MUT forms intracellular aggregates, increases ER stress, and induces UPR activation in rat pancreatic AR4-2J cells [116]. The UPR then induces NF- $k \mathrm{~B}$ activation and promotes apoptosis [116].

In any case, if CEL-MUT variant aggregates are poisonous for cells - and particularly for beta cells in the pancreatic gland - it is assumed $[115,117]$ that these aggregates might be formed at the basolateral region of the membrane in order to be taken up by proximal beta cells.

Pancreatic acinar cells are polarized cells, which enables the flow of pancreatic enzymes within pancreatic ducts. If impairment of protein transport or modification of secretory pathways occurs in CEL-MUT-expressing pancreatic acinar cells, this may explain the retention of the truncated protein within the cell and the formation of aggregates (further presented at the cell surface). In physiological conditions, BSDL present in the duodenum after pancreatic secretion crosses the intestinal barrier by means of a transcytosis mechanism [118, 119] to reach the bloodstream $[29,30]$. The protein is then cleared from the blood by renal glomerulus filtration, and is detected in the urine of healthy subjects [120]. Only some variants of mutated BSDL are detected in patients' urine [115], with the exception of CEL-MUT and CEL-Ins4 [115], likely due to antibodies used in this study and/or to the low rate of CEL-MUT secretion [112]. Interestingly, Xiao et al. [116] have suggested that the intracellular accumulation of CEL-MUT in acinar cells can lead to chronic pancreatitis, the earliest symptom observed in childhood [113, 114], ending with MODY-8 diabetes [69, 112].

It is therefore proposed that MODY-8 is defined as a protein misfolding disease resulting from the expression of mutated BSDL $[115,116]$. However, results of Xiao et al. [116] could be partially overstated, as the commercial cDNA encoding CEL and CEL-MUT used to transfect cell models in this study contains a three base-pair inframe deletion (p.E365del). Although E365 is well conserved during evolution, the deletion of this aminoacid residue located in the surface loop consisting of $\alpha \mathrm{I}$ and $\alpha \mathrm{J}$ helixes [37] seems not to affect the enzyme activity, and is not sufficient by itself to trigger activation of the UPR and cell death [121]. In fine, CEL-MUT causes chronic pancreatitis, meaning that the MODY-8 diabetes symptoms are not isolated effects of CEL-MUT expression [116]. Nonetheless BSDL knock-out mice do not develop pancreatic dysfunction [122]. In light of the proposed mechanism leading to the pathology with the retention of the misfolded protein and the activation the UPR answer [115], the absence of the CEL-MUT expression therefore explains this negative result. Transgenic mice expressing CEL-MUT also do not develop pancreatic dysfunction [123]. Many reasons may explain this negative result: 1) the mouse models may not be relevant for this particular pathology, as its development takes place over many years; 2) the genetic background may obscure the effects of mutation [123]; and finally, 3) the role of BSDL may vary between species, possibly due to differences in the number of repeats [11].

\section{Pancreatitis}

In this review, we will not discuss acute pancreatitis, in which the serum level of many pancreatic enzymes is greatly increased. Indeed, serum levels of BSDL are significantly increased in patients suffering from acute interstitial pancreatitis or necrotizing pancreatitis [110]. A high serum level of BSDL, therefore, even where 
serum levels of amylase are normal [124], suggests acute pancreatitis [125].

Progressing over time, chronic pancreatitis is a pancreatic inflammatory disease. Clinicians have no therapeutic solution to prevent recurrent episodes and progression to chronic pancreatitis. This absence of effective therapy could in part be due to limited knowledge of the pathophysiology of this disease. People with genetically susceptible backgrounds are prone to develop chronic pancreatitis once exposed to environmental factors (smoking, alcohol) [126]. The risk of pancreatitis increases with alcohol consumption [127], which disrupts defense mechanisms and/or enhances injury-associated pathways through alteration of gene expression. BSDL, which displays fatty acid ethyl ester- and cholesteryl ester generating activity [128-130], may be involved in this process [131]. Indeed, normally found in zymogen granules within the acinar cells of the pancreas, BSDL is also detected in the cytoplasm during acinar cell necrosis [132]. Alcohol, by increasing the expression of lysosomal and digestive pancreatic enzymes, also increases organelle fragility, which could result in prematurely activated digestive enzymes that can damage the tissue integrity.

Most reported genes associated with chronic pancreatitis that have been identified up to now code for proteins linked to the protease-antiprotease system of acinar cells, such as the cationic and anionic trypsinogen (PRSS1 and 2), chymotrypsinogen C (CTRC), carboxypeptidase A1 (CPA1), or the Kasal-type 1 protease inhibitor (SPINK1) [133]. None of these genes are associated with pancreatic adenocarcinoma, at least in German patients [134]. Albeit associated with modest odds ratios, the $\mathrm{ABO}$, FUT2, and CFTR loci represent risk factors for chronic pancreatitis [133, 135].

Although VNTR numbers in the BSDL gene do not represent a risk factor for alcoholic and idiopathic chronic pancreatitis [136, 137], a recombined allele resulting from nonallelic homologous recombination occurring between BSDL intron 10 and intron 10' of its tandemly linked BSDL pseudogene, $B S D L P$, has to be added to the list of genes involved in nonalcoholic chronic pancreatitis [138]. This recombined allele, referred to as CEL-HYB (Figure 2 ), was first discovered in a cohort of patients of European ancestry with familial chronic pancreatitis, and further detected in patients with idiopathic chronic pancreatitis [138]. CEL-HYB was present in $0.7 \%$ of the control cohorts and in $3.7 \%$ of the case group cohort, underlining a substantial chronic pancreatitis risk associated with the recombined allele (odds ratio $=5.2$ ). Among reported CEL-HYB-positive subjects, none expressed the mutated PRSS1 risk variant [138]. The CEL-HYB allele encodes a chimeric BSDL protein; the protein is 589 amino acids long, with a functional catalytic site and a truncated C-terminal domain with three repeats encoded by a short VNTR originating from the BSDL pseudogene with a modified $\mathrm{C}$-terminal amino acid sequence (i.e.
RVCPRPCNG instead of KEAQMPAVIRF [11]). This chimeric protein shows reduced cellular clearance and decreased secretion rate [138] suggesting that the chimeric protein may be more stable than the wildtype protein. An alternative hybrid allele, which codes for another chimeric CEL (CEL-HYB2), has been characterized in three independent cohorts from China, Japan, and India [139]. However, this variant, which harbors premature stop codon within its chimeric exon 10 , is devoid of VNTR [142]. CEL-HYB2 is not associated with chronic pancreatitis. $C E L-H Y B$ [138] (also referred to as $C E L$ $H Y B 1$ [139]) is not detected in Asian populations [139] and could be a chronic pancreatitis risk factor specific for Caucasian populations.

In fact, CEL-HYB shows impaired secretion, decreased activity on synthetic substrates, and retention within acinar cells. The observed increase in the LC3-II autophagy marker in human cell models shows that the retention of the chimeric protein promotes autophagy [138], a dysfunction described as a key event in pancreatitis $[140,141]$. Autophagy associated with chronic pancreatitis cooperates with Kras to promote pancreatic cancer [142]. Most carriers of CEL-HYB in the population do not develop pathology, suggesting that other factors may participate in the inflammatory process and in the susceptibility of individuals $[143,144]$. On the other hand, Xiao et al. [116] showed that CEL-MUT forms insoluble aggregates, likely due to the formation of inappropriate disulfide bridges. These aggregates are the cause of ER stress and trigger the UPR in the acinar cell model [116], promote elF $2 \alpha$ phosphorylation [115], induce cell death by apoptosis, and promote NF- $k$ B activation [116]. ER stress and NF- $k \mathrm{~B}$ activation are early pathogenic features in pancreatitis [145]. As suggested above, pancreatitis could be an early event in MODY- 8 diabetes. It should be noted that no case of diabetes is described in subjects expressing CEL-HYB [138].

\section{Pancreatic adenocarcinoma}

The most frequently occurring pancreatic cancers are $\mathrm{PAC}$, and arise from preneoplastic lesions of the pancreas called pancreatic intraepithelial neoplasia (PanIN). Larger lesions, such as intraductal papillary mucinous neoplasms (IPMN) and mucinous cystic neoplasms, may also be PAC precursors. PAC are complex diseases involving genomic, epigenetic, and metabolic modifications. They exhibit aberrant signaling pathways promoting cell survival, proliferation, migration, and invasion, ending with the formation of distal metastases.

A genome-wide association study (GWAS) metaanalysis identifies several susceptibility loci in the p21 region of chromosome 9 that are associated with the pathogenesis of multiple cancers, including pancreatic cancer [146]. Single nucleotide polymorphisms (SNPs) at this locus may have heterogeneous effects i.e. result in 
increased or decreased susceptibility. Albeit modestly, the risk for pancreatic cancer is also associated with another locus on chromosome 9, the ABO locus in the q34 region, which was the first common pancreatic cancer risk locus [147] and controversially associated with patient survival [148-152] Although the cohort size was too small to reach genome-wide significance, data of Qi et al. [153] strongly suggest that the ABO locus also presents linkage with type 2 diabetes. Yet GWAS susceptibility variants are unlikely to explain the potential genetic etiology shared between type 2 diabetes and pancreatic cancer [154]. To the best of our knowledge, only one publication links chronic pancreatitis to ABO blood type-B groups in Northeastern German population. In this population, group $\mathrm{O}$ appears to have protective effects [155]. Germline or somatic mutations that are present in the GC-rich segment of chromosome 9 where the BSDL gene is located are not accessible by mass sequencing [156], and careful examinations of electropherograms obtained after Sanger sequencing are essential to detect them.

\section{Germline and somatic mutations}

Pancreatic cancers are characterized by many somatic mutations, some of which are particularly prevalent [3]. The most common is that of the Kras oncogene which appears at the beginning of the carcinogenesis. It takes more than ten years from the appearance of the first mutation for the pathology to be established. We recently reported that a c. $1719 \mathrm{C}>\mathrm{T}$ transition (SNP, $r s 488087)$ can be detected in BSDL VNTR (Figure 2) [157]. This SNP could be a useful marker for defining a population at risk of developing pancreatic cancer (occurrence: $63.90 \%$ in the pancreatic cancer versus $27.30 \%$ in the control group) particularly if associated with other potential risk factor of PAC [158]. This SNP needs to be validated in a larger cohort of patients and healthy people before being used as a tool to predict pancreatic cancer [158]. The odds ratio of 4.7 for the $\mathrm{T}$ allele is larger than those determined for other SNPs thought to be predictive of pancreatic cancer [158]. The transition c. $1719 \mathrm{C}>\mathrm{T}$ occuring in the third position of a codon, results in no change of encoded amino acid residue (synonymous SNP). The protein sequence is thus unchanged. Our in silico studies [158] indicate that the SNP rs488087: 1) does not seem to induce alteration of mRNA splicing; and 2) may induce a change in the secondary structure of the BSDL mRNA, and thus has a possible impact on the processing of RNA and translation into protein. The transition c.1719C $>\mathrm{T}$ also generates a loss of binding site for the miRNA miR564 , which has been further shown to have no impact on BSDL expression. Examining pancreatic tissue of patients afflicted with a PAC suggested that the T allele may correlate with Kras G12R/G12D somatic mutations. These Kras mutations are associated with a bad prognosis and reduced survival [159-161].
Although VNTR length polymorphisms do not represent a risk for pancreatic cancer [162], a BSDL transcript in which a cytosine residue is inserted into the VNTR (BSDL-InsC) was recently detected in a cohort of French patients with PAC [163]. This insertion, which could not be detected in DNA extracted from blood samples from a cohort of control individuals [163], gives rise to a premature stop codon, resulting in a truncated protein and a modification of the C-terminal amino acid sequence - that is, GAPPRAAHG instead of KEAQMPAVIRF (Figure 2) [11, 163]. While all human tissue samples are positive to anti-PAVIRF antibodies, in this study $72.2 \%$ of pancreatic tumor tissue samples reacted positively with anti-PRAAHG antibodies, particularly in dysplastic areas of the tumor in contrast to neoplastic cells with ductal differentiation. Examining a cohort of normal Norwegian individuals, Raeder et al. [112] detected a germline insertion of one base in certain VNTR of BSDL with an allelic frequency of some $10 \%$. Although the outcome of these individuals is unknown one hypothesis to explain this allelic frequency in the Norwegian population could be a genetic variation between populations of Northern [112] and from Southern [164] Europe. This last point may be illustrated by many studies in part those of Tian et al. [164] and Seldin et al. [165]. Around 70\% of PanIN tissue samples were also reactive to anti-PRAAHG antibodies, suggesting that the $\mathrm{C}$ insertion occurs early during pancreatic carcinogenesis. Anti-PRAAHG antibodies are exclusively reactive to a truncated variant of BSDL. The truncated BSDL reactive to antibodies raised against the PRAAHG sequence (BSDL-InsC) was present in the pancreatic juice of patients with PAC [165]. Yet the low secretion rate that is due to the retention of truncated BSDL, as observed in SOJ-6 tumor cell model, partly results from an impaired transport [104]. Nonetheless, detection of truncated BSDL reactive to antibodies against the PRAAHG $\mathrm{C}$-terminal sequence in pancreatic juice or in pancreatic biopsies may be a new tool in the early diagnosis of PAC.

\section{$\boldsymbol{O}$-glycosylation alterations of BSDL}

The fetoacinar pancreatic protein or FAPP, characterized by a glycotope recognized by J28 monoclonal antibodies and thus designated the J28 glycotope, is a specific component of acinar cells of the human pancreas associated with ontogenesis and development of the gland [166]. Maximum synthesis of FAPP [167] occurs when acinar cell proliferation is maximal, then declines until parturition [168]. Interestingly, FAPP also appears during carcinogenesis $[168,169]$. FAPP presents many homologies with BSDL [172] and its cloning from human pancreatic tumor cells [170] indicates that the sequence of the N-terminal domain of FAPP is identical to that encoded by exons 1-10 of $B S D L$. The sequence that corresponds to exon 11 
(which itself encodes the BSDL tandem repeats), however, is deleted by $330 \mathrm{bp}$ and codes for six repeats. FAPP exhibits decreased activity both on synthetic substrates and on cholesteryl ester [169]. Therefore, FAPP has been characterized as a genotypic and phenotypic variant of
BSDL bearing the J28 oncofetal glycotope [171]. FAPP is now referred to as pathological BSDL-J28 $8^{+}$(pBSDL-J28 ${ }^{+}$) $[172,173]$. pBSDL-J28 ${ }^{+}$, which is $N$ - and $O$-glycosylated [170] and phosphorylated [64], is poorly secreted by pancreatic tumor cells [96, 104, 168, 174]. In tumor cells,

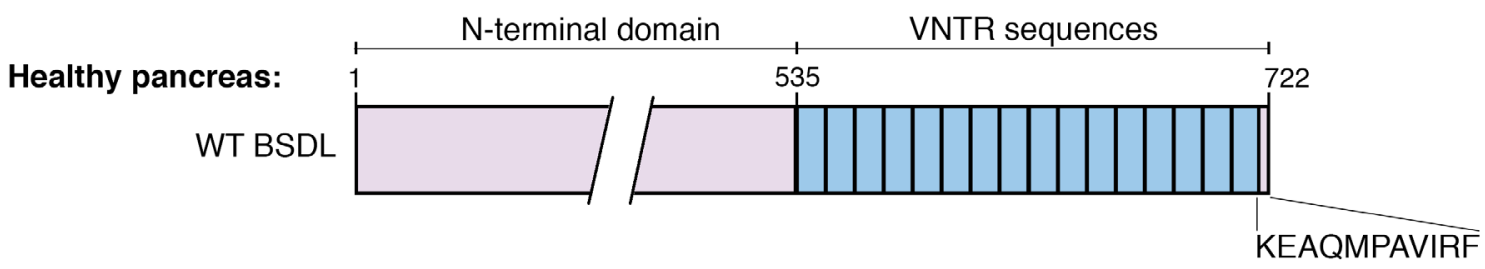

MODY-8 Diabetes:

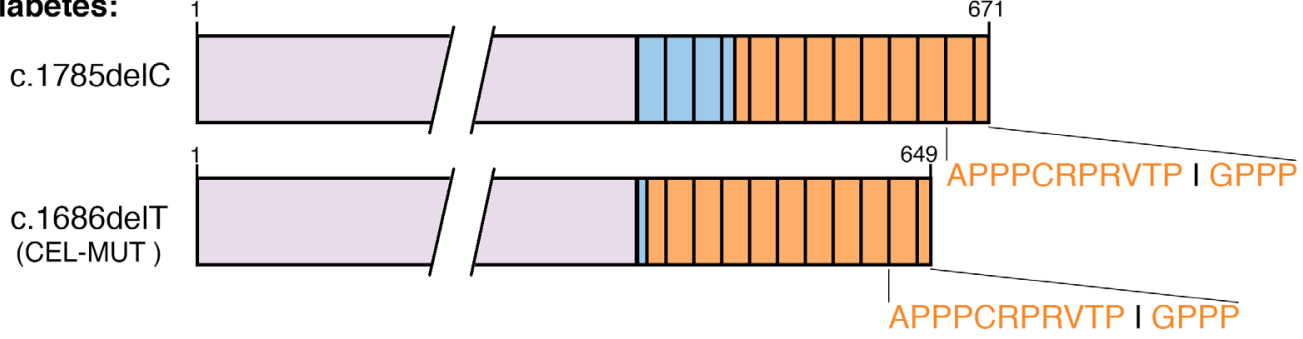

Chronic Pancreatitis:

CEL-HYB
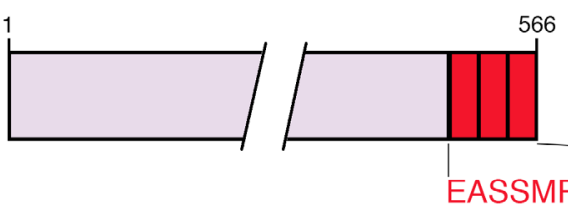

EASSMPSTGDS I EATPVSPDRQL I RVCPRPCNG

PAC:

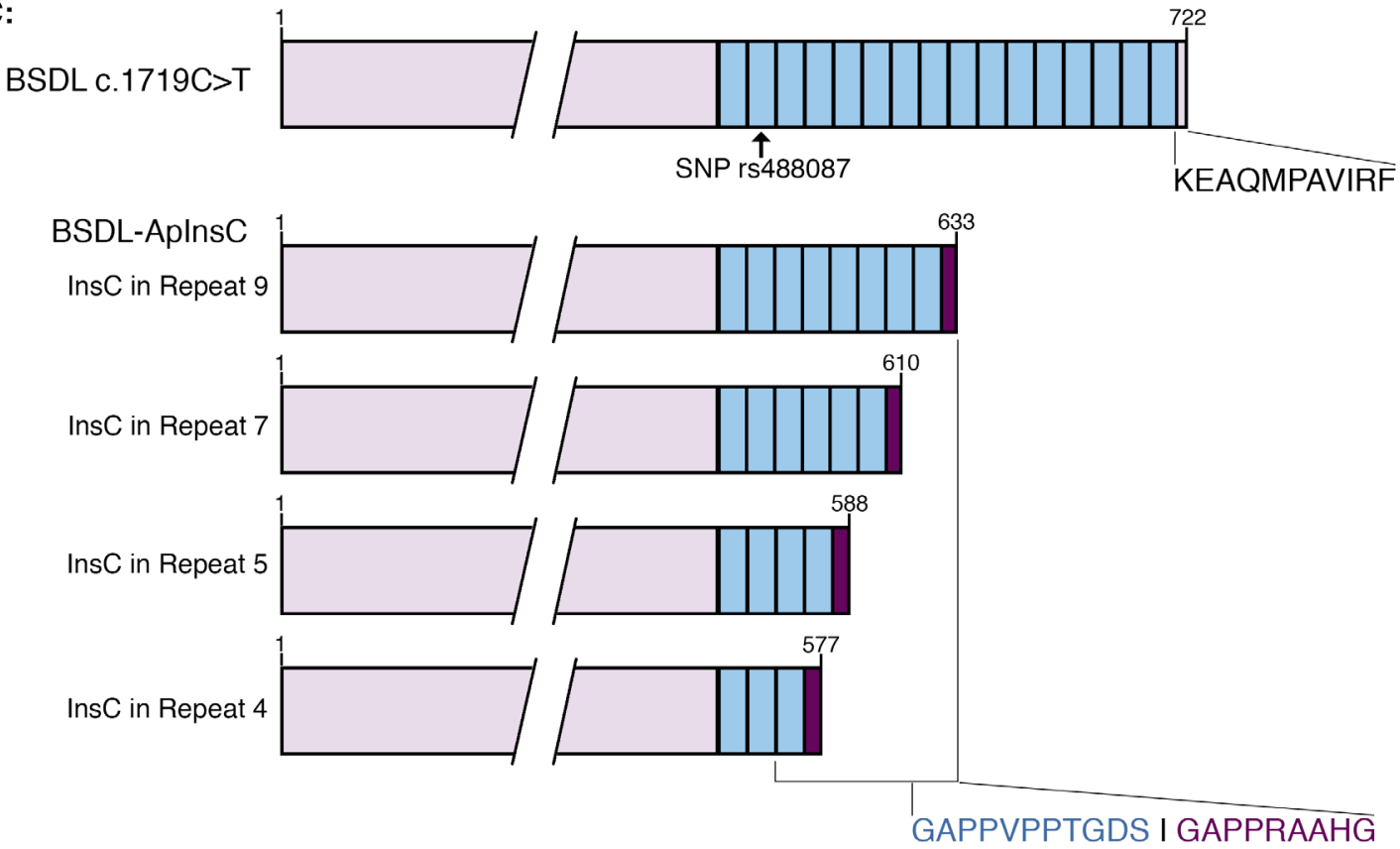

Figure 2: Schematic representations of human BSDL variants and associated pathologies. The sequences of exons 1 to 10 encoding the N-terminal domain of BSDL are represented in purple. VNTR sequences are in blue; each box represents a single VNTR. The sequences of the VNTR that are modified upon mutation (i.e., insertion, deletion), or recombination are colored in orange (MODY-8 diabetes), red (chronic pancreatitis), or dark purple (PAC), along with the corresponding C-terminal sequence of the protein. 
pBSDL-J28+, which is typically membrane-associated, distributes within the plasma membrane and the ER and Golgi membranes [174]. This protein retention, which occurs alongside modifications in the expression of glycosyltransferase resulting from neoplastic processes in the pancreas [175], could result in J28 glycotope formation; this requires the $\alpha(1-3 / 4)$ fucosyltransferase and the Core $2 \beta-1,6-\mathrm{N}$-acetylglucosaminyltransferase [176]. These enzymes are typically found in the trans- or cis-Golgi compartments [177]. As previously observed in PAC, MODY-8 diabetes, and chronic pancreatitis, aberrant variants of BSDL (BSDL-InsC, CEL-MUT, CEL-HYB) with impaired secretion should either be degraded [96] or presented at the cell surface as aggregates and further degraded after recapture [117]. However, it is not known whether these aberrant variants of BSDL are likely to bear the J28 epitope. How such expression and cell retention of BSDL variants end up with pancreatic dysfunction and diseases is an open question (see diabetes section above).

\section{Immunogenicity of pBSDL-J28 ${ }^{+}$and potential applications}

The pBSDL-J $28^{+}$captured by human immature dendritic cells (iDC) via the mannose receptor is degraded in late endosomes $[172,173]$. Glycopeptides derived from this degradation, including the one bearing the J28 glycotope, may then be expressed and presented by MHC II for presentation to naive T cells. Human and murine DC loaded with pBSDL-J28 $8^{+}$or with the C-terminal domain of BSDL bearing the $\mathrm{J} 28$ glycotope (C-ter-J $\left.28^{+}\right)$induced the proliferation of $\mathrm{CD}^{+}{ }^{+}$and $\mathrm{CD} 8^{+}$T-lymphocytes $[172,173$, 178]. In addition, we showed in the murine model that this proliferation accompanies IFN- $\gamma$ expression and expansion of granzyme B-expressing $\mathrm{CD} 8^{+} \mathrm{T}$-cells [178]. These findings demonstrate that interactions of pBSDL-J28, expressed on tumor pancreatic tissue, with DC may lead to adequate antigen trafficking and processing, and result in $\mathrm{T}$ cell activation. This makes it a candidate for antitumor DC-vaccination. Indeed, prophylactic and therapeutic C-ter-J28+-DC-vaccinations reduce ectopic tumor growth induced by the syngeneic tumor pancreatic line, Panc02 cells, provide long-lasting protection from Panc02-tumor development in $100 \%$ of $\mathrm{C} 57 \mathrm{BL} / 6 \mathrm{Jr}$ mice, and attenuate orthotopic progression of tumors and metastases as revealed by magnetic resonance imaging [178]. C-ter$\mathrm{J} 28^{+}$-DC-vaccinations represent a potential adjuvant therapy for patients with PAC.

\section{Biological effects of BSDL variants bearing the $16 \mathrm{D} 10$ glycotope and potential applications}

In addition to the $\mathrm{J} 28$ glycotope, the BSDL variants may carry another tumor-associated carbohydrate antigen (TACA). This glycosylated epitope recognized by $16 \mathrm{D} 10$ monoclonal antibodies (mAb16D10) is thus designated the 16D10 glycotope [179-181]. The 16D10 glycotope is linked to the blood group A antigen [182]. The J28 and 16D10 glycotopes are formed due to cell sugar metabolism modifications that occur during carcinogenesis. While undetectable at the plasma membranes of normal cells, 16D10 TACA can be presented at the surface of pancreatic tumor cells (as can the J28 glycotope) [179]. How this reactive material is presented at the cell surface remains to be determined. There are a number of non-exclusive possibilities, including membrane presentation [183] of the glycopeptides that are generated by degradation of the BSDL variants could be facilitated by Grp94, which assists BSDL in folding and in intracellular transport [8]. Another possibility is the generation of putative sites for palmitoylation and membrane anchoring in repeat sequences, as detected in silico, of some variants of BSDL. A third possibility is that aggregated material is presented, as described for CEL-MUT $[115,116]$. Analysis of the biological effects of mAb16D10 reveals interesting information [181]. The mAb16D10 decreases pancreatic tumor growth in vivo by triggering antibody-dependent cell-mediated cytotoxicity (ADCC). In addition, mAb16D10 triggers a cell-cycle arrest in the G1/S phase, by modifying the expression of cyclin D1, p53, or GSK-3 $\beta$, followed by cell death. Anchoring of the 16D10-bearing-BSDL variant by means of fatty acid in lipid rafts acting as a signaling platform [184] may explain the apoptotic effects of mAb16D10 [181]. Such antibodies could serve to detect TACA in addition to their potential use as therapy to fight tumor cells.

\section{Role of vascular BSDL and variants}

In physiological conditions BSDL present in the duodenum after pancreatic secretion crosses the intestinal barrier $[118,119]$ to reach the bloodstream $[29,30]$. Vascular BSDL binds to the CXCR4 platelet receptor via its V3-like loop [66] and acts as a weak agonist pseudo-chemokine to optimize the aggregation of platelets and the formation of venous thrombosis [65, 185]. This favors the formation of pre-metastatic niches [186]. In the context of neoplastic diseases, in particular pancreatic cancers, it is reasonable to assume that BSDL, which forms an equimolar complex with ApoB100 in low density lipoprotein (LDL) [30], can be captured by cancer cells via the over-expressed LDL receptor [187]. Also, BSDL present in microparticles [185] and/or exosomes [188] released by pancreatic cancer cells can be captured via endocytosis or by means of fusion with the plasma membrane [188]. This holds true for noncancer cells residing in the tumor, such as fibroblasts or immune cells [189]. The presence of BSDL in microparticles [185] and exosomes [188] could exacerbate the thrombotic events that are frequently observed in patients with PAC [190]. Thrombosis may be essential for cancer cell dissemination and metastasis formation [191]. Thus, once established, the tumor may benefit from circulating BSDL. 


\section{Impact of BSDL variants activity on lipid metabolism}

\section{Role of vascular BSDL in lipid metabolism}

Several lines of evidence point to the impact of vascular BSDL on lipid metabolism. Vascular BSDL modulates lipids associated with LDL and high-density lipoprotein (HDL), resulting in cellular protection against the cytotoxic effects of lysophosphatidylcholine, and plays a role in the induction of proliferation and cell migration [39, 192]. Moreover, as BSDL can convert large LDL to smaller, more atherogenic LDL entities, it may play a role in atherogenesis [193]. An association between the number of C-terminal repeats and serum cholesterol profile is reported, and individuals carrying a short allele of BSDL have lower total cholesterol and LDL cholesterol levels than subjects carrying two common alleles [194], meaning that BSDL variants may have implications in vascular lipid metabolism. The vascular role of BSDL is strengthened by the observation that BSDL can be activated by physiological concentrations of plateletactivating factor [45]. The ABO blood group locus, which is proximal to the BSDL locus, is also associated with lipid phenotype [195-197]. Thus, it is hypothesized that the association between lipid profile and the $\mathrm{ABO}$ locus could be due to BSDL gene polymorphism [46].

\section{Role of cell BSDL in lipid metabolism}

Lipids are essential cell components that provide cells with energy, act as signaling intermediates, and build biological membranes. Lipids are permanently recycled and redistributed within cells where they orchestrate apoptosis [198], autophagy [199], and inflammation [200]. A pancreatic cell model chronically treated with ethanol showed a specific accumulation of BSDL in the cytosol compartment [201], where BSDL may affect cholesterol metabolism leading to cholesteryl ester storage within cytosolic lipid droplets [202]. A similar role in cholesterol homeostasis is attributed to BSDL expressed in steroidogenic tissue, adrenal glands and testis [31], and macrophages [35]. All BSDL variants characterized to date are partly retained within acinar cells and present with a decreased activity (generally determined on synthetic substrates), but specificity studies are rare [203].

\section{Lipid metabolism modifications in pancreatic pathologies}

Fat infiltration is an early event in nondiabetic MODY-8 VNTR mutation carriers with signs of exocrine dysfunction [114] that meet the criteria for chronic pancreatitis [116]. Dyslipidemia is associated with an inflammatory status in patients with diabetes
[204]. Truncated BSDL activity may be affected as the C-terminal domain modulates its activity $[63,74]$. It is known that branched fatty esters of hydroxyl fatty acids (FAHFAs) present protective effects against diabetes, with anti-inflammatory activities [205]. A recent study demonstrates that FAHFAs are the preferred substrate for CEL-MUT [203]. Any perturbation in the BSDL variant homeostasis, associated with different enzymatic properties, leading to its retention within the cell, could induce active degradation of these protective endogenous FAHFAs. Suppression of the anti-inflammatory activity of FAHFAs upon BSDL hydrolysis may cause diabetes. Overall, these data suggested that deletion in VNTR, such as c.1686delT, leads to modification of the CEL specificity. Therefore, it can be hypothesized that any BSDL/CEL variant with VNTR mutations may have different specificity than that of the non-mutated enzyme.

Fatty pancreatic infiltration is a risk factor for early lesions in pancreatic cancer [206], and lipid metabolism is dysregulated in PAC [209-211]. Metabolic reprogramming occurs in tumor cells to foster their rapid proliferation, their survival, and the formation of metastasis [207]. This reprogramming also supports the inflammation observed in neoplastic pathologies [208, 209]. Fatty acid synthase (FASN, also known as onco-antigen 519), a key lipogenic enzyme involved in de novo lipid biosynthesis, is significantly upregulated in pancreatic tumor cells, which results in a significantly poor prognosis of patients [210]. It is now clear that patients with pancreatic cancers present markers of tissue wasting [211] at a stage when the tumor is not yet clinically detectable, and therefore these markers present potential interest.

While the expression of BSDL - and likely that of any variant - is decreased in differentiated PAC [182], BSDL variants could play an important role in pre-neoplasia [163]. However, variation in BSDL expression levels may not be so central to pancreatic pathologies such as chronic pancreatitis, MODY-8, and PAC. Most relevant is which BSDL variant(s) is (are) expressed, and what its (their) activity and specificity is on relevant physiological substrates.

Collectively, all these data suggest that BSDL variants (BSDL-InsC, CEL-MUT, CEL-HYB, BSDL-J $28^{+}$, and any other not yet characterized variant that cannot be detected by mass sequencing or "omics" studies) that are expressed and retained within acinar cells, or present in blood circulation and captured by any cell within the tumor, could be implicated in the cellular lipid metabolism reprogramming observed in pancreatic pathologies [204, 206-208]. For example, BSDL associated with LDL can be captured by pancreatic cancer cells by means of the over-expressed LDL receptor and can therefore participate in lipid metabolism reprogramming. A strong link between chronic pancreatitis, diabetes, and PAC may therefore reside in lipid metabolism modifications. These modifications 
can result in exocrine cell dysfunction and inflammatory processes. This may further induce chronic pancreatitis and/or MODY-8 diabetes, with pancreatic cancer then most likely to occur when other predisposing factors exist (perhaps SNP rs488087 on BSDL?) in conjunction with mutations such as those of Kras (Figure 3).

\section{CONCLUSIONS}

The expression of variants of BSDL appears to be a convergent point for chronic pancreatitis, diabetes, and pancreatic adenocarcinoma (Figure 4).

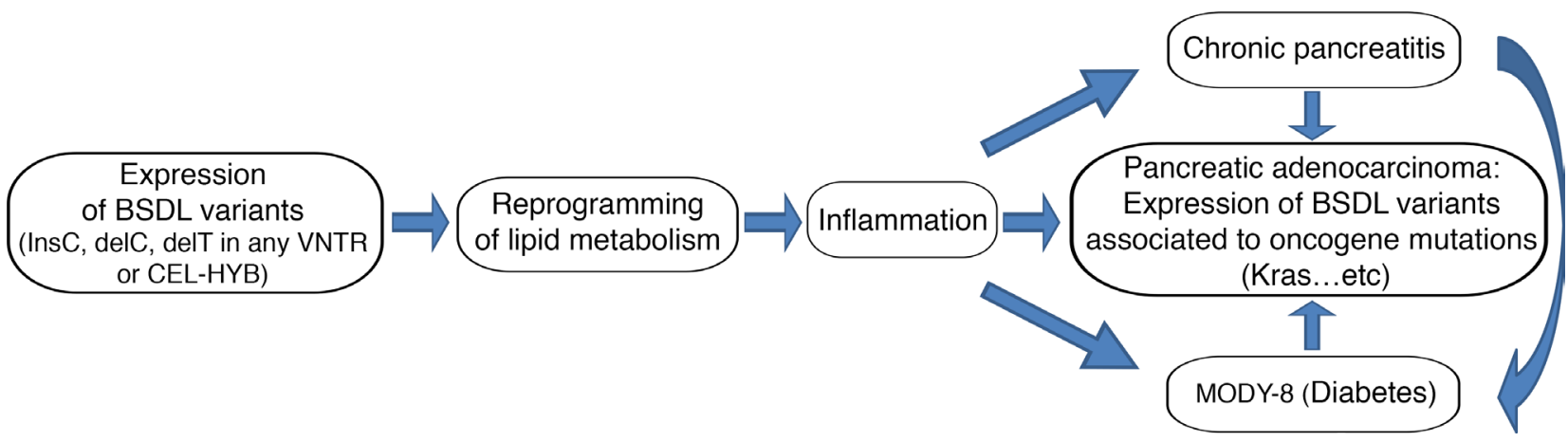

Figure 3: Schematic representation of the putative link between pancreatic pathologies and the variants of BSDL. This shows the potential pathophysiological consequences of expression of human BSDL variants.

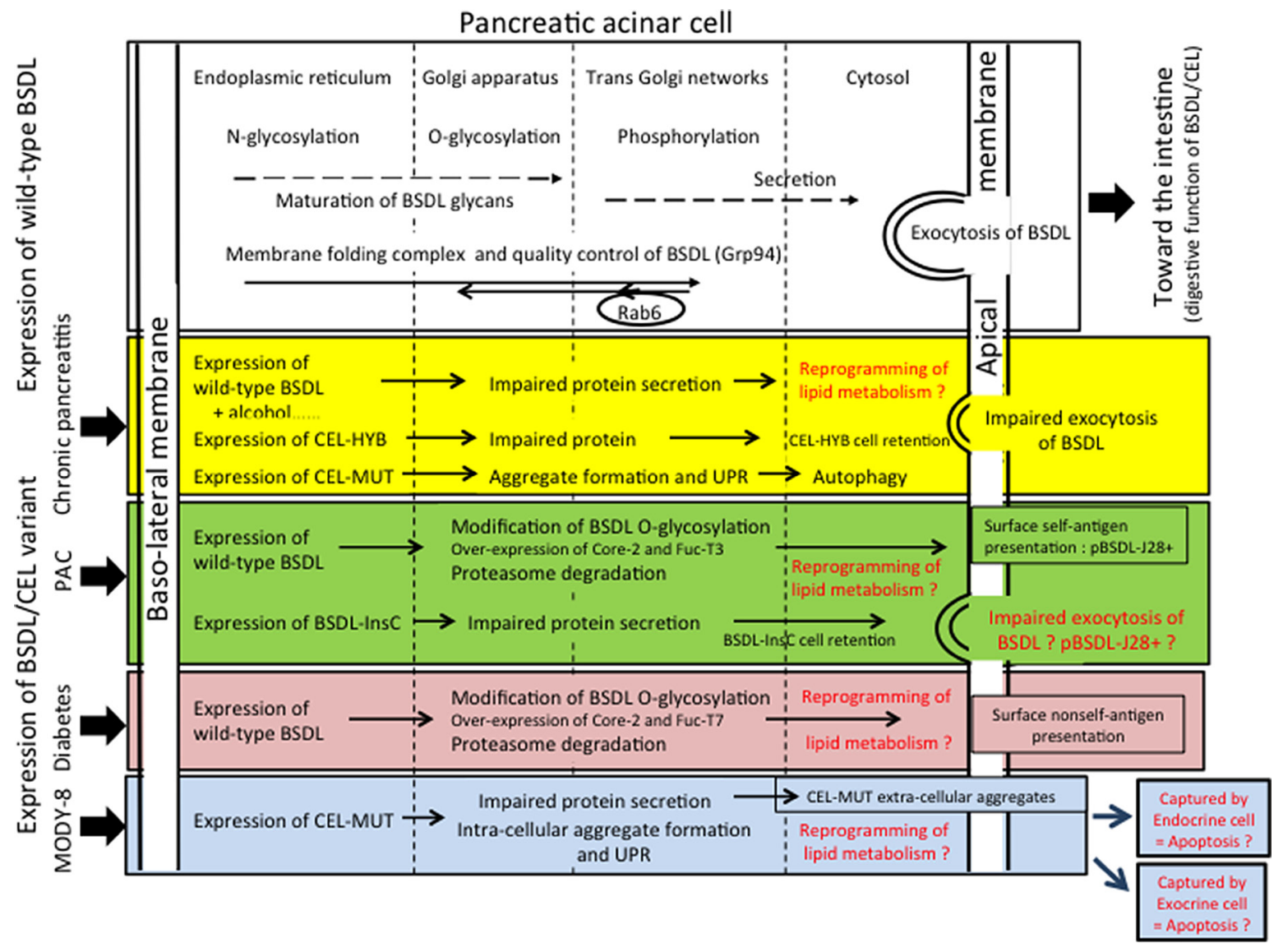

Figure 4: Tentative model to illustrate the involvement of the expression of BSDL/CEL variants and that of wild-type BSDL/CEL bearing post-translational modifications in pancreatic diseases. Note that post-translational modifications of BSDL variants may also be affected by the pathophysiological status of exocrine cell. In red characters are putative mechanisms impacting the pathophysiological status of exocrine or endocrine pancreatic cells. Core 2, $\beta$ (1-6) $N$-acetylglucosaminyltransferase; Fuc-T3 and Fuc-T7, Fucosyltransferase 3 and 7; UPR, unfolded protein response. 
The findings obtained up to now show that: 1) a deletion of a single base within the BSDL (CEL) gene segment encoding VNTR leads to exocrine dysfunction and MODY-8 symptoms with beta-cell failure and pancreatic exocrine disease [112], 2) an insertion of a cytosine within any VNTR of $B S D L$ leads to the expression of a new BSDL isoform in dysplastic areas and pre-neoplastic lesions of the exocrine pancreas [163], 3 ) a recombined allele of the $B S D L$ gene and $B S D L$ pseudogene confers susceptibility to chronic pancreatitis $[138], 4)$ all these mutations or recombinations in $B S D L$ are predicted to give rise to DNA encoding truncated proteins with a functional catalytic site.

Therefore, variants of BSDL/CEL with different $\mathrm{C}$-terminal domains may be expressed as active monomers that have different activity/specificity than the wild-type BSDL, as seen with CEL-MUT [203]. These variants, that are partly retained within cells, may impact differently on the cell lipid metabolism involved in the development of pancreatic pathologies. This hypothesis, which opens new paths for research, is compatible with a progression of pancreatic disease development that is: expression of a misfolded BSDL/CEL, impaired secretion and degradation of the protein, leading to apoptosis/autophagy $[115,116$, 138], or to reduced viability of acinar cells [117].

Such sequential mechanisms can lead to pancreatic pathologies in which active BSDL/CEL variants present within the acinar cells may play a central role together with an impaired protein homeostasis impacting the cell/ tissue lipid metabolism (such as hydrolysis of FAHFAs, cholesteryl ester synthesis, etc), which in fine results in lipid metabolism reprogramming and in inflammatory processes followed by cell failure, cell death, or carcinogenesis.

Therefore, targeting BSDL activity by means of inhibition might be an option in developing new therapies against these pancreatic pathologies. From this perspective, the use of BSDL-specific inhibitors such as carbamates, WWL92 [212], and N-butyl-N-methyl-4-nitrophenyl carbamate [213], might be explored as potentially useful drugs.

\section{Abbreviations}

BSDL, bile salt-dependent lipase; CEL, carboxyl ester lipase; FAPP, fetoacinar pancreatic protein; PAC, pancreatic adenocarcinoma; MODY, maturity onset diabetes of the young; SNP, single nucleotide polymorphism.

\section{ACKNOWLEDGMENTS}

Dominique Lombardo would like to address his special thanks to collaborators, students, staff researchers, and technicians who have worked on BSDL/CEL (formerly known as carboxylic ester hydrolase) since 1978. Some of them coauthor this review. The list is too long to give here, but it has been a great and very rewarding pleasure.

\section{CONFLICTS OF INTEREST}

The authors declare no conflicts of interest.

\section{GRANT SUPPORT}

This work was supported by institutional funding from INSERM (Paris, France), the Aix-Marseille Université (Marseille, France), and by a grant-in-aid INCa-DGSO-INSERM 6038 to the Comprehensive Cancer Center of Marseille (SIRIC-Marseille).

\section{REFERENCES}

1. Rahib L, Smith BD, Aizenberg R, Rosenzweig AB, Fleshman JM, Matrisian LM. Projecting cancer incidence and deaths to 2030: the unexpected burden of thyroid, liver, and pancreas cancers in the United States. Cancer Res. 2014; 74:2913-2921.

2. Vincent A, Herman J, Schulick R, Hruban RH, Goggins M. Pancreatic cancer. Lancet. 2011; 378:607-620.

3. Kleeff J, Korc M, Apte M, La Vecchia C, Johnson CD, Biankin AV, Neale RE, Tempero M, Tuveson DA, Hruban RH, Neoptolemos JP. Pancreatic cancer. Nat Rev Dis Primers. 2016; 2:16022.

4. Pliarchopoulou K, Pectasides D. Pancreatic cancer: current and future treatment strategies. Cancer Treatment Review. 2009; 35:431-436.

5. Becker AE, Hernandez YG, Frucht H, Lucas AL. Pancreatic ductal adenocarcinoma: risk factors, screening, and early detection. World J Gastroenterol. 2014; 20:11182-11198.

6. Amundadottir LT. Pancreatic Cancer Genetics. Int J Biol Sci. 2016; 12:314-325.

7. Hocevar BA, Kamendulis LM, Pu X, Perkins SM, Wang ZY, Johnston EL, DeWitt JM, Li L, Loehrer PJ, Klaunig JE, Chiorean EG. Contribution of environment and genetics to pancreatic cancer susceptibility. PLoS One. 2014; 9: e90052.

8. Lombardo D. Bile salt-dependent lipase: its pathophysiological implications. Biochim Biophys Acta. 2001; 1533:1-28.

9. Gjellesvik DR, Lombardo D, Walther BT. Pancreatic bile salt dependent lipase from cod (Gadus morhua): purification and properties. Biochim Biophys Acta. 1992; 1124:123134.

10. Lombardo D, Guy O, Figarella C. Purification and characterization of a carboxyl ester hydrolase from human pancreatic juice. Biochim Biophys Acta. 1978; 527:142149.

11. Sbarra V, Bruneau N, Mas E, Hamosh M, Lombardo D, Hamosh P. Molecular cloning of the bile salt-dependent lipase of ferret lactating mammary gland: an overview of functional residues. Biochim Biophys Acta. 1998; 1393:80-89. 
12. Lombardo D, Fauvel J, Guy O. Studies on the substrate specificity of a carboxyl ester hydrolase from human pancreatic juice. I. Action on carboxyl esters, glycerides and phospholipids. Biochim Biophys Acta. 1980; 611:136-146.

13. Lombardo D, Guy O. Studies on the substrate specificity of a carboxyl ester hydrolase from human pancreatic juice. II. Action on cholesterol esters and lipid-soluble vitamin esters. Biochim Biophys Acta. 1980; 611:147-155.

14. Kirby RJ, Zheng S, Tso P, Howles PN, Hui DY. Bile saltstimulated carboxyl ester lipase influences lipoprotein assembly and secretion in intestine: a process mediated via ceramide hydrolysis. J Biol Chem. 2002; 277:4104-4109.

15. Nyberg L, Farooqi A, Bläckberg L, Duan RD, Nilsson A, Hernell O. Digestion of ceramide by human milk bile salt-stimulated lipase. J Pediatr Gastroenterol Nutr. 1998; 27:560-567.

16. Howles PN, Carter CP, Hui DY. Dietary free and esterified cholesterol absorption in cholesterol esterase (bile saltstimulated lipase) gene-targeted mice. J Biol Chem. 1996; 271:7196-7202.

17. Nilsson J, Bläckberg L, Carlsson P, Enerbäck S, Hernell O, Bjursell G. cDNA cloning of human-milk bile-saltstimulated lipase and evidence for its identity to pancreatic carboxylic ester hydrolase. Eur J Biochem. 1990; 192:543550.

18. Baba T, Downs D, Jackson KW, Tang J, Wang CS. Structure of human milk bile salt activated lipase. Biochemistry. 1991; 30:500-510.

19. Hernell O, Olivecrona T. Human milk lipases. II. Bile saltstimulated lipase. Biochim Biophys Acta. 1974; 369:234 244.

20. Hernell O, Bläckberg L. Human milk bile salt-stimulated lipase: functional and molecular aspects. J Pediatr. 1994; 125:S56-61.

21. Hui DY, Kissel JA. Sequence identity between human pancreatic cholesterol esterase and bile salt-stimulated milk lipase. FEBS Lett. 1990; 276:131-134.

22. Alemi B, Hamosh M, Scanlon JW, Salzman-Mann C, Hamosh P. Fat digestion in very low-birth-weight infants: effect of addition of human milk to low-birth-weight formula. Pediatrics. 1981; 68:484-489.

23. Lebenthal E, Lee PC. Development of functional responses in human exocrine pancreas. Pediatrics. 1980; 66:556-560.

24. Reiner DS, Wang CS, Gillin FD. Human milk kills Giardia lamblia by generating toxic lipolytic products. J Infect Dis. $1986 ; 154: 825-832$.

25. Howles PN, Stemmerman GN, Fenoglio-Preiser CM, Hui DY. Carboxyl ester lipase activity in milk prevents fatderived intestinal injury in neonatal mice. Am J Physiol. 1999; 277:G653-G661.

26. Lucas A, Cole TJ. Breast milk and neonatal necrotising enterocolitis. Lancet. 1990; 336:1519-1523.

27. Gillin FD, Reiner DS, Wang CS. Human milk kills parasitic intestinal protozoa. Science. 1983; 221:1290-1292.
28. Kabara JJ. Lipids as host-resistance factors of human milk. Nutr Rev. 1980; 38:65-73.

29. Caillol N, Pasqualini E, Mas E, Guieu R, Valette A, Boyer J, Lombardo D. Pancreatic bile-salt-dependent lipase activity in serum of diabetic patients : is there a relationship with glycation? Clin Sci (Lond). 1998; 94:181-188.

30. Caillol N, Pasqualini E, Mas E, Valette A, Verine A, Lombardo D. Pancreatic bile salt-dependent lipase activity in serum of normolipidemic patients. Lipids. 1997; 32:1147-1153.

31. Lee TG, Lee YH, Kim JH, Kim HS, Suh PG, Ryu SH. Immunological identification of cholesterol ester hydrolase in the steroidogenic tissues, adrenal glands and testis. Biochim Biophys Acta. 1997; 1346:103-108.

32. Li F, Hui DY. Synthesis and secretion of the pancreatic-type carboxyl ester lipase by human endothelial cells. Biochem J. 1998; 329:675-679.

33. Shamir R, Johnson WJ, Morlock-Fitzpatrick K, Zolfaghari R, Li L, Mas E, Lombardo D, Morel DW, Fisher EA. Pancreatic carboxyl ester lipase: a circulating enzyme that modifies normal and oxidized lipoproteins in vitro. J Clin Invest. 1996; 97:1696-1704.

34. Holtsberg FW, Ozgur LE, Garsetti DE, Myers J, Egan RW, Clark MA. Presence in human eosinophils of a lysophospholipase similar to that found in the pancreas. Biochem J. 1995; 309:141-144.

35. Kodvawala A, Ghering AB, Davidson WS, Hui DY. Carboxyl ester lipase expression in macrophages increases cholesteryl ester accumulation and promotes atherosclerosis. J Biol Chem. 2005; 280:38592-38598.

36. La Rosa S, Vigetti D, Placidi C, Finzi G, Uccella S, Clerici M, Bartolini B, Carnevali I, Losa M, Capella C. Localization of carboxyl ester lipase in human pituitary gland and pituitary adenomas. J Histochem Cytochem. 2010; 58:881-889.

37. Holmes RS, Cox LA. Comparative Structures and Evolution of Vertebrate Carboxyl Ester Lipase (CEL) Genes and Proteins with a Major Role in Reverse Cholesterol Transport. Cholesterol. 2011; 2011:781643.

38. Li F, Hui DY. Modified low density lipoprotein enhances the secretion of bile salt-stimulated cholesterol esterase by human monocyte-macrophages. species-specific difference in macrophage cholesteryl ester hydrolase. J Biol Chem. 1997; 272:28666-28671.

39. Augé N, Rebaï O, Lepetit-Thévenin J, Bruneau N, Thiers JC, Mas E, Lombardo D, Negre-Salvayre A, Vérine A. Pancreatic bile salt-dependent lipase induces smooth muscle cells proliferation. Circulation. 2003; 108:86-91.

40. Zolfaghari R, Harrison EH, Ross AC, Fisher EA. Expression in Xenopus oocytes of rat liver mRNA coding for a bile salt-dependent cholesteryl ester hydrolase. Proc Natl Acad Sci U S A. 1989; 86:6913-6916.

41. Zolfaghari R, Glick JM, Fisher EA. The effects of varying the expression of a neutral cholesteryl ester hydrolase on 
the turnover of cholesteryl ester in rat hepatoma cells. J Biol Chem. 1993; 268:13532-13538.

42. Li F, Huang Y, Hui DY. Bile salt stimulated cholesterol esterase increases uptake of high density lipoproteinassociated cholesteryl esters by HepG2 cells. Biochemistry. 1996; 35:6657-6663.

43. Chen X, Harrison EH, Fisher EA. Molecular cloning of the cDNA for rat hepatic, bile salt-dependent cholesteryl ester/retinyl ester hydrolase demonstrates identity with pancreatic carboxylester lipase. Proc Soc Exp Biol Med. 1997; 215:186-191.

44. van Bennekum AM, Li L, Piantedosi R, Shamir R, Vogel S, Fisher EA, Blaner WS, Harrison EH. Carboxyl ester lipase overexpression in rat hepatoma cells and CEL deficiency in mice have no impact on hepatic uptake or metabolism of chylomicron-retinyl ester. Biochemistry. 1999; 38:4150-4156.

45. Fontbonne H, Puigserver A, Bouza B, Lombardo D, Ajandouz el H. Activation of bile salt dependent lipase by (lyso)phosphatidic acid and platelet activating factor. FEBS Lett. 2013; 587:3002-3007.

46. Taylor AK, Zambaux JL, Klisak I, Mohandas T, Sparkes RS, Schotz MC, Lusis AJ. Carboxyl ester lipase: a highly polymorphic locus on human chromosome 9qter. Genomics. 1991; 10:425-431.

47. Mohandas T, Sparkes RS, Sparkes MC, Shulkin JD, Toomey KE, Funderburk SJ. Regional localization of human gene loci on chromosome 9: studies of somatic cell hybrids containing human translocations. Am J Hum Genet. 1979; 31:586-600.

48. Baba T, Downs D, Jackson KW, Tang J, Wang CS. Structure of human milk bile salt activated lipase. Biochemistry. 1991; 30:500-510.

49. Wang CS, Dashti A, Jackson KW, Yeh JC, Cummings RD, Tang J. Isolation and characterization of human milk bile salt-activated lipase C-tail fragment. Biochemistry. 1995; 34:10639-10644.

50. DiPersio LP, Fontaine RN, Hui DY. Identification of the active site serine in pancreatic cholesterol esterase by chemical modification and site-specific mutagenesis. J Biol Chem. 1990; 265:16801-16806.

51. DiPersio LP, Hui DY. Aspartic acid 320 is required for optimal activity of rat pancreatic cholesterol esterase. J Biol Chem. 1993; 268:300-304.

52. DiPersio LP, Fontaine RN, Hui DY. Site-specific mutagenesis of an essential histidine residue in pancreatic cholesterol esterase. J Biol Chem. 1991; 266:4033-4036.

53. Lombardo D. Catalytic properties of modified carboxylic ester hydrolase. Biochim Biophys. Acta. 1982; 700:75-80.

54. Wang X, Wang CS, Tang J, Dyda F, Zhang XC. The crystal structure of bovine bile salt activated lipase: insights into the bile salt activation mechanism. Structure. 1997; 5:12091218.

55. Winkler FK, D'Arcy A, Hunziker W. Structure of human pancreatic lipase. Nature. 1990; 343:771-774.
56. Lombardo D, Guy O. Binding of human pancreatic carboxylic ester hydrolase to lipid interfaces. Biochim Biophys Acta. 1981; 659:401-410.

57. Bosner MS, Gulick T, Riley DJ, Spilburg CA, Lange LG. Receptor-like function of heparin in the binding and uptake of neutral lipids. Proc Natl Acad Sci USA. 1988; 85:74387442 .

58. Bruneau N, Lombardo D. Chaperone function of a Grp 94-related protein for folding and transport of the pancreatic bile salt-dependent lipase. J Biol Chem. 1995; 270:1352413533.

59. Bläckberg L, Hernell O. Bile salt-stimulated lipase in human milk. Evidence that bile salt induces lipid binding and activation via binding to different sites. FEBS Lett. 1993; 323:207-210.

60. Terzyan S, Wang CS, Downs D, Hunter B, Zhang XC. Structure of the catalytic domain of human bile salt activated lipase. Protein Sci. 2000; 9:1783-1790.

61. Loomes KM, Senior HE. Bile salt activation of human cholesterol esterase does not require protein dimerisation. FEBS Lett. 1997; 405:369-372.

62. Gjellesvik DR, Lorens JB, Male R. Pancreatic carboxylester lipase from Atlantic salmon (Salmo salar). cDNA sequence and computer-assisted modelling of tertiary structure. Eur J Biochem. 1994; 226:603-612.

63. Liang Y, Medhekar R, Brockman HL, Quinn DM, Hui DY. Importance of arginines 63 and 423 in modulating the bile salt-dependent and bile salt-independent hydrolytic activities of rat carboxyl ester lipase. J Biol Chem. 2000; 275:24040-24046.

64. Verine A, Le Petit-Thevenin J, Panicot-Dubois L, Valette A, Lombardo D. Phosphorylation of the oncofetal variant of the human bile salt-dependent lipase. Identification of phosphorylation site and relation with secretion process. J Biol Chem. 2001; 276:12356-12361.

65. Aubert-Jousset E, Garmy N, Sbarra V, Fantini J, Sadoulet MO, Lombardo D. The combinatorial extension method reveals a sphingolipid binding domain on pancreatic bile salt-dependent lipase: role in secretion. Structure. 2004; 12:1437-1447.

66. Panicot-Dubois L, Thomas GM, Furie BC, Furie B, Lombardo D, Dubois C. Bile salt-dependent lipase interacts with platelet CXCR4 and modulates thrombus formation in mice and humans. J Clin Invest. 2007; 117:3708-3719.

67. Aubert-Jousset E, Sbarra V, Lombardo D. Site-directed mutagenesis of the distal basic cluster of pancreatic bile salt-dependent lipase. J Biol Chem. 2004; 279:3969739704.

68. Higuchi S, Nakamura Y, Saito S. Characterization of a VNTR polymorphism in the coding region of the CEL gene. J Hum Genet. 2002; 47:213-215.

69. Torsvik J, Johansson S, Johansen A, Ek J, Minton J, Raeder H, Ellard S, Hattersley A, Pedersen O, Hansen T, Molven A, Njølstad PR. Mutations in the VNTR of the carboxyl-ester 
lipase gene (CEL) are a rare cause of monogenic diabetes. Hum Genet. 2010; 127:55-64.

70. Lindquist S, Bläckberg L, Hernell O. Human bile saltstimulated lipase has a high frequency of size variation due to a hypervariable region in exon 11. Eur J Biochem. 2002; 269:759-767.

71. Hansson L, Bläckberg L, Edlund M, Lundberg L, Strömqvist M, Hernell O. Recombinant human milk bile salt-stimulated lipase. Catalytic activity is retained in the absence of glycosylation and the unique proline-rich repeats. J Biol Chem. 1993; 268:26692-26698.

72. Downs D, Xu YY, Tang J, Wang CS. Proline-rich domain and glycosylation are not essential for the enzymic activity of bile salt-activated lipase. Kinetic studies of T-BAL, a truncated form of the enzyme, expressed in Escherichia coli. Biochemistry. 1994; 33:7979-7985.

73. Bläckberg L, Strömqvist $M$, Edlund M, Juneblad K, Lundberg L, Hansson L, Hernell O. Recombinant humanmilk bile-salt-stimulated lipase. Functional properties are retained in the absence of glycosylation and the unique proline-rich repeats. Eur J Biochem. 1995; 228:817-821.

74. DiPersio LP, Carter CP, Hui DY. Exon 11 of the rat cholesterol esterase gene encodes domains important for intracellular processing and bile salt-modulated activity of the protein. Biochemistry. 1994; 33:3442-3448.

75. Morlock-Fitzpatrick KR, Fisher EA. The effects of Oand N-linked glycosylation on the secretion and bile saltstimulation of pancreatic carboxyl ester lipase activity. Proc Soc Exp Biol Med. 1995; 208:186-190.

76. Loomes KM, Senior HE, West PM, Roberton AM. Functional protective role for mucin glycosylated repetitive domains. Eur J Biochem. 1999; 266:105-111.

77. Madeyski K, Lidberg U, Bjursell G, Nilsson J. Characterization of the gorilla carboxyl ester lipase locus, and the appearance of the carboxyl ester lipase pseudogene during primate evolution. Gene. 1999; 239:273-282.

78. Nilsson J, Hellquist M, Bjursell G. The human carboxyl ester lipase-like (CELL) gene is ubiquitously expressed and contains a hypervariable region. Genomics. 1993; 17:416-422.

79. Roudani S, Miralles F, Margotat A, Escribano MJ, Lombardo D. Bile salt-dependent lipase transcripts in human fetal tissues. Biochim Biophys Acta. 1995; 1264:141-150.

80. Madeyski K, Lidberg U, Bjursell G, Nilsson J. Structure and organization of the human carboxyl ester lipase locus. Mamm Genome. 1998; 9:334-338.

81. Lidmer AS, Kannius M, Lundberg L, Bjursell G, Nilsson J. Molecular cloning and characterization of the mouse carboxyl ester lipase gene and evidence for expression in the lactating mammary gland. Genomics. 1995; 29:115-122.

82. Christie DL, Cleverly DR, O'Connor CJ. Human milk bile-salt stimulated lipase. Sequence similarity with rat lysophospholipase and homology with the active site region of cholinesterases. FEBS Lett. 1991; 278:190-194.
83. Kumar VB, Sasser T, Mandava JB, al Sadi H, Spilburg C. Identification of 5' flanking sequences that affect human pancreatic cholesterol esterase gene expression. Biochem Cell Biol. 1997; 75:247-254.

84. Lidberg U, Kannius-Janson M, Nilsson J, Bjursell G. Transcriptional regulation of the human carboxyl ester lipase gene in exocrine pancreas. Evidence for a unique tissue-specific enhancer. J Biol Chem. 1998; 273:3141731426 .

85. Kruse F, Rose SD, Swift GH, Hammer RE, MacDonald RJ. Cooperation between elements of an organ-specific transcriptional enhancer in animals. Mol Cell Biol. 1995; 15:4385-4394.

86. Roux E, Strubin M, Hagenbüchle O, Wellauer PK. The cellspecific transcription factor PTF1 contains two different subunits that interact with the DNA. Genes Dev. 1989; 3:1613-1624.

87. Kannius-Janson M, Lidberg U, Bjursell G, Nilsson J. The tissue-specific regulation of the carboxyl ester lipase gene in exocrine pancreas differs significantly between mouse and human. Biochem J. 2000; 351:367-376.

88. Fukuoka S, Zhang DE, Taniguchi Y, Scheele GA. Structure of the canine pancreatic colipase gene includes two proteinbinding sites in the promoter region. J Biol Chem. 1993; 268:11312-11320.

89. Nganga A, Bruneau N, Sbarra V, Lombardo D, Le PetitThevenin J. Control of pancreatic bile-salt-dependentlipase secretion by the glucose-regulated protein of $94 \mathrm{kDa}$ (Grp94). Biochem J. 2000; 352:865-874.

90. Kissel JA, Fontaine RN, Turck CW, Brockman HL, Hui DY. Molecular cloning and expression of cDNA for rat pancreatic cholesterol esterase. Biochim Biophys Acta. 1989; 1006:227-236.

91. Reue K, Zambaux J, Wong H, Lee G, Leete TH, Ronk M, Shively JE, Sternby B, Borgström B, Ameis D, Schotz MG. cDNA cloning of carboxyl ester lipase from human pancreas reveals a unique proline-rich repeat unit. J Lipid Res. 1991; 32:267-276.

92. Han JH, Stratowa C, Rutter WJ. Isolation of full-length putative rat lysophospholipase cDNA using improved methods for mRNA isolation and cDNA cloning. Biochemistry. 1987; 26:1617-1625.

93. Kyger EM, Wiegand RC, Lange LG. Cloning of the bovine pancreatic cholesterol esterase/lysophospholipase. Biochem Biophys Res Commun. 1989; 164:1302-1309.

94. Colwell NS, Aleman-Gomez JA, Kumar BV. Molecular cloning and expression of rabbit pancreatic cholesterol esterase. Biochim Biophys Acta. 1993; 1172:175-180.

95. Abouakil N, Mas E, Bruneau N, Benajiba A, Lombardo D. Bile salt-dependent lipase biosynthesis in rat pancreatic AR 4-2 J cells. Essential requirement of $\mathrm{N}$-linked oligosaccharide for secretion and expression of a fully active enzyme. J Biol Chem. 1993; 268:2575525763. 
96. Le Petit-Thevenin J, Verine A, Nganga A, Nobili O, Lombardo D, Bruneau N. Impairment of bile salt-dependent lipase secretion in AR4-2J rat pancreatic cells induces its degradation by the proteasome. Biochim Biophys Acta. 2001; 1530:184-198.

97. Pasqualini E, Caillol N, Mas E, Bruneau N, Lexa D, Lombardo D. Association of bile-salt-dependent lipase with membranes of human pancreatic microsomes is under the control of ATP and phosphorylation. Biochem J. 1997; 327:527-535.

98. Clairmont CA, De Maio A, Hirschberg CB. Translocation of ATP into the lumen of rough endoplasmic reticulum-derived vesicles and its binding to luminal proteins including $\mathrm{BiP}$ (GRP 78) and GRP 94. J Biol Chem. 1992; 267:3983-3990.

99. Bruneau N, Nganga A, Fisher EA, Lombardo D. O-Glycosylation of C-terminal tandem-repeated sequences regulates the secretion of rat pancreatic bile salt-dependent lipase. J Biol Chem. 1997; 272:27353-27361.

100. Bruneau N, de la Porte PL, Sbarra V, Lombardo D. Association of bile-salt-dependent lipase with membranes of human pancreatic microsomes. Eur J Biochem. 1995; 233:209-218.

101. Pasqualini E, Caillol N, Valette A, Lloubes R, Verine A, Lombardo D. Phosphorylation of the rat pancreatic bilesalt-dependent lipase by casein kinase II is essential for secretion. Biochem J. 2000; 345:121-128.

102. Melnick J, Dul JL, Argon Y. Sequential interaction of the chaperones BiP and GRP94 with immunoglobulin chains in the endoplasmic reticulum. Nature. 1994; 370:373-375.

103. Bruneau N, Lombardo D, Bendayan M. Participation of GRP94-related protein in secretion of pancreatic bile saltdependent lipase and in its internalization by the intestinal epithelium. J Cell Sci. 1998; 111:2665-2679.

104. Caillol N, Pasqualini E, Lloubes R, Lombardo D. Impairment of bile salt-dependent lipase secretion in human pancreatic tumoral SOJ-6 cells. J Cell Biochem. 2000; 79:628-647.

105. White J, Johannes L, Mallard F, Girod A, Grill S, Reinsch S, Keller P, Tzschaschel B, Echard A, Goud B, Stelzer EH. Rab6 coordinates a novel Golgi to ER retrograde transport pathway in live cells. J Cell Biol. 1999; 147:743-760.

106. Sugo T, Mas E, Abouakil N, Endo T, Escribano MJ, Kobata A, Lombardo D. The structure of N-linked oligosaccharides of human pancreatic bile-salt-dependent lipase. Eur J Biochem. 1993; 216:799-805.

107. Mas E, Abouakil N, Roudani S, Franc JL, Montreuil J, Lombardo D. Variation of the glycosylation of human pancreatic bile-salt-dependent lipase. Eur J Biochem. 1993; 216:807-812.

108. Panicot L, Mas E, Thivolet C, Lombardo D. Circulating antibodies against an exocrine pancreatic enzyme in type 1 diabetes. Diabetes. 1999; 48:2316-2323.

109. Wiese TJ, Dunlap JA, Yorek MA. Effect of L-fucose and D-glucose concentration on L-fucoprotein metabolism in human Hep G2 cells and changes in fucosyltransferase and alpha-L-fucosidase activity in liver of diabetic rats. Biochim Biophys Acta. 1997; 1335:61-72.

110. Blind PJ, Büchler M, Bläckberg L, Andersson Y, Uhl W, Beger HG, Hernell O. Carboxylic ester hydrolase. A sensitive serum marker and indicator of severity of acute pancreatitis. Int J Pancreatol. 1991; 8:65-73.

111. Lombardo D, Montalto G, Roudani S, Mas E, Laugier R, Sbarra V, Abouakil N. Is bile salt-dependent lipase concentration in serum of any help in pancreatic cancer diagnosis? Pancreas. 1993; 8:581-588.

112. Ræder H, Johansson S, Holm PI, Haldorsen IS, Mas E, Sbarra V, Nermoen I, Eide SA, Grevle L, Bjørkhaug L, Sagen JV, Aksnes L, Søvik O, et al. Mutations in the CEL VNTR cause a syndrome of diabetes and pancreatic exocrine dysfunction. Nat Genet. 2006; 38:54-62.

113. Ræder H, Haldorsen IS, Ersland L, Grüner R, Taxt T, Søvik O, Molven A, Njølstad PR. Pancreatic lipomatosis is a structural marker in nondiabetic children with mutations in carboxyl-ester lipase. Diabetes. 2007; 56:444-449.

114. Ræder H, McAllister FE, Tjora E, Bhatt S, Haldorsen I, Hu J, Willems SM, Vesterhus M, El Ouaamari A, Liu M, Ræder MB, Immervoll H, Hoem D, et al. Carboxyl-ester lipase maturity-onset diabetes of the young is associated with development of pancreatic cysts and upregulated MAPK signaling in secretin stimulated duodenal fluid. Diabetes. 2014; 63:259-269.

115. Johansson BB, Torsvik J, Bjørkhaug L, Vesterhus M, Ragvin A, Tjora E, Fjeld K, Hoem D, Johansson S, Ræder H, Lindquist S, Hernell O, Cnop M, et al. Diabetes and pancreatic exocrine dysfunction due to mutations in the carboxyl ester lipase gene-maturity onset diabetes of the young (CEL-MODY): a protein misfolding disease. J Biol Chem. 2011; 286:34593-34605.

116. Xiao X, Jones G, Sevilla WA, Stolz DB, Magee KE, Haughney M, Mukherjee A, Wang Y, Lowe ME. A Carboxyl Ester Lipase (CEL) Mutant Causes Chronic Pancreatitis by Forming Intracellular Aggregates that Activate Apoptosis. J Biol Chem. 2016; 291:23224-23236.

117. Torsvik J, Johansson BB, Dalva M, Marie M, Fjeld K, Johansson S, Bjørkøy G, Saraste J, Njølstad PR, Molven A. Endocytosis of secreted carboxyl ester lipase in a syndrome of diabetes and pancreatic exocrine dysfunction. J Biol Chem. 2014; 289:29097-29111.

118. Bruneau N, Nganga A, Bendayan M, Lombardo D. Transcytosis of pancreatic bile salt-dependent lipase through human Int407 intestinal cells. Exp Cell Res. 2001; 271:94-108.

119. Bruneau N, Bendayan M, Gingras D, Ghitescu L, Levy E, Lombardo D. Circulating bile salt-dependent lipase originates from the pancreas via intestinal transcytosis. Gastroenterology. 2003; 124:470-480.

120. Comte B, Franceschi C, Sadoulet MO, Silvy F, Lafitte D, Benkoel L, Nganga A, Daniel L, Bernard JP, Lombardo D, 
Mas E. Detection of bile salt-dependent lipase, a $110 \mathrm{kDa}$ pancreatic protein, in urines of healthy subjects. Kidney Int. 2006; 69:1048-1055.

121. Xiao X, Jones G, Sevilla WA, Stolz DB, Magee KE, Haughney M, Mukherjee A, Wang Y, Lowe ME. A carboxyl ester lipase (CEL) mutant causes chronic pancreatitis by forming intracellular aggregates that activate apoptosis. J Biol Chem. 2017; 292:7744.

122. Vesterhus M, Raeder H, Kurpad AJ, Kawamori D, Molven A, Kulkarni RN, Kahn CR, Njølstad PR. Pancreatic function in carboxyl-ester lipase knockout mice. Pancreatology. 2010; 10:467-476.

123. Ræder H, Vesterhus M, El Ouaamari A, Paulo JA, McAllister FE, Liew CW, Hu J, Kawamori D, Molven A, Gygi SP, Njølstad PR, Kahn CR, Kulkarni RN. Absence of diabetes and pancreatic exocrine dysfunction in a transgenic model of carboxyl-ester lipase-MODY (maturity-onset diabetes of the young). PLoS One. 2013; 8:e60229.

124. Blind PJ, Bläckberg L, Lundström EB, Emdin SO, Hernell O. Carboxylic ester hydrolase and amylase in ischemic pancreatitis in the guinea pig. Pancreas. 1996; 12:388-395.

125. Blind PJ, Bläckberg L, Hernell O, Ljungberg B. Carboxylic ester hydrolase: a serum marker of acute pancreatitis. Pancreas. 1987; 2:597-603.

126. Whitcomb DC, Frulloni L, Garg P, Greer JB, Schneider A, Yadav D, Shimosegawa T. Chronic pancreatitis: An international draft consensus proposal for a new mechanistic definition. Pancreatology. 2016; 16:218-224.

127. Majumder S, Chari ST. Chronic pancreatitis. Lancet. 2016; 387:1957-1966.

128. Lombardo D, Guy O. Effect of alcohols on the hydrolysis catalyzed by human pancreatic carboxylic-ester hydrolase. Biochim Biophys Acta. 1981; 657:425-437.

129. Lombardo D, Deprez P, Guy O. Esterification of cholesterol and lipid-soluble vitamins by human pancreatic carboxyl ester hydrolase. Biochimie. 1980; 62:427-432.

130. Bhat SG, Brockman HL. The role of cholesteryl ester hydrolysis and synthesis in cholesterol transport across rat intestinal mucosal membrane: a new concept. Biochem Biophys Res Commun. 1982; 109:486-492.

131. Pfützer RH, Tadic SD, Li HS, Thompson BS, Zhang JY, Ford ME, Eagon PK, Whitcomb DC. Pancreatic cholesterol esterase, ES-10, and fatty acid ethyl ester synthase III gene expression are increased in the pancreas and liver but not in the brain or heart with long-term ethanol feeding in rats. Pancreas. 2002; 25:101-116.

132. Aho HJ, Sternby B, Kallajoki M, Nevalainen TJ. Carboxyl ester lipase in human tissues and in acute pancreatitis. Int $\mathbf{J}$ Pancreatol. 1989; 5:123-134.

133. Ravi Kanth V, Nageshwar Reddy D. Genetics of acute and chronic pancreatitis: An update. World J Gastrointest Pathophysiol. 2014; 5:427-437.

134. Schubert S, Traub F, Brakensiek K, von Kopylow K, Marohn B, Maelzer M, Gaedcke J, Kreipe H, Stuhrmann
M. CFTR, SPINK1, PRSS1, and CTRC mutations are not associated with pancreatic cancer in German patients. Pancreas. 2014; 43:1078-1082.

135. Weiss FU, Schurmann C, Guenther A, Ernst F, Teumer A, Mayerle J, Simon P, Völzke H, Radke D, Greinacher A, Kuehn JP, Zenker M, Völker U, et al. Fucosyltransferase 2 (FUT2) non-secretor status and blood group B are associated with elevated serum lipase activity in asymptomatic subjects, and an increased risk for chronic pancreatitis: a genetic association study. Gut. 2015; 64:646-656.

136. Ragvin A, Fjeld K, Weiss FU, Torsvik J, Aghdassi A, Mayerle J, Simon P, Njølstad PR, Lerch MM, Johansson S, Molven A. The number of tandem repeats in the carboxyl-ester lipase (CEL) gene as a risk factor in alcoholic and idiopathic chronic pancreatitis. Pancreatology. 2013; 13:29-32.

137. Fjeld K, Beer S, Johnstone M, Zimmer C, Mössner J, Ruffert C, Krehan M, Zapf C, Njølstad PR, Johansson S, Bugert P, Miyajima F, Liloglou T, et al. Length of variable numbers of tandem repeats in the carboxyl ester lipase (CEL) gene may confer susceptibility to alcoholic liver cirrhosis but not alcoholic chronic pancreatitis. PLoS One. 2016; 11:e0165567.

138. Fjeld K, Weiss FU, Lasher D, Rosendahl J, Chen JM, Johansson BB, Kirsten H, Ruffert C, Masson E, Steine SJ, Bugert P, Cnop $\mathrm{M}$, Grützmann R, et al. A recombined allele of the lipase gene CEL and its pseudogene CELP confers susceptibility to chronic pancreatitis. Nat Genet. 2015; 47:518-522.

139. Zou WB, Boulling A, Masamune A, Issarapu P, Masson E, Wu H, Sun XT, Hu LH, Zhou DZ, He L, Fichou Y, Nakano E, Hamada S, et al. No Association Between CELHYB Hybrid Allele and Chronic Pancreatitis in Asian Populations. Gastroenterology. 2016; 150:1558-1560.

140. Fortunato F, Bürgers H, Bergmann F, Rieger P, Büchler MW, Kroemer G, Werner J. Impaired autolysosome formation correlates with Lamp-2 depletion: role of apoptosis, autophagy, and necrosis in pancreatitis. Gastroenterology. 2009; 137:350-360.

141. Gukovskaya AS, Pandol SJ, Gukovsky I. New insights into the pathways initiating and driving pancreatitis. Curr Opin Gastroenterol. 2016; 32:429-435.

142. Loncle C, Molejon MI, Lac S, Tellechea JI, Lomberk G, Gramatica L, Fernandez Zapico MF, Dusetti N, Urrutia $\mathrm{R}$, Iovanna JL. The pancreatitis-associated protein VMP1, a key regulator of inducible autophagy, promotes Kras(G12D)-mediated pancreatic cancer initiation. Cell Death Dis. 2016; 7:e2295.

143. Molven A, Njølstad PR, Weiss FU. Lipase gene fusion: a new route to chronic pancreatitis. Oncotarget. 2016; 6:30443-30444. https://doi.org/10.18632/oncotarget.5454.

144. Molven A, Fjeld K, Lowe ME. Lipase Genetic Variants in Chronic Pancreatitis: When the End Is Wrong, All's Not Well. Gastroenterology. 2016; 150:1515-1518.

145. Sah RP, Garg SK, Dixit AK, Dudeja V, Dawra RK, Saluja AK. Endoplasmic reticulum stress is chronically activated in chronic pancreatitis. J Biol Chem. 2014; 289:27551-27561. 
146. Li WQ, Pfeiffer RM, Hyland PL, Shi J, Gu F, Wang Z, Bhattacharjee S, Luo J, Xiong X, Yeager M, Deng X, Hu N, Taylor PR, et al. Genetic polymorphisms in the 9p21 region associated with risk of multiple cancers. Carcinogenesis. 2014; 35:2698-2705.

147. Wolpin BM, Kraft P, Gross M, Helzlsouer K, Bueno-deMesquita HB, Steplowski E, Stolzenberg-Solomon RZ, Arslan AA, Jacobs EJ, Lacroix A, Petersen G, Zheng W, Albanes D, et al. Pancreatic cancer risk and ABO blood group alleles: results from the pancreatic cancer cohort consortium. Cancer Res. 2010; 70:1015-1023.

148. Rizzato C, Campa D, Pezzilli R, Soucek P, Greenhalf W, Capurso G, Talar-Wojnarowska R, Heller A, Jamroziak K, Khaw KT, Key TJ, Bambi F, Landi S, et al. ABO blood groups and pancreatic cancer risk and survival: results from the PANcreatic Disease ReseArch (PANDoRA) consortium. Oncol Rep. 2013; 29:1637-1644.

149. Dandona M, Gao F, Linehan DC, Wang-Gillam A. ABO blood group and the risk of pancreatic cancer. J Natl Cancer Inst. 2010; 102:135-137.

150. Engin H, Bilir C, Üstün H, Gökmen A. ABO blood group and risk of pancreatic cancer in a Turkish population in Western Blacksea region. Asian Pac J Cancer Prev. 2012; $13: 131$.

151. Li D, Morris JS, Liu J, Hassan MM, Day RS, Bondy ML, Abbruzzese JL. Body mass index and risk, age of onset, and survival in patients with pancreatic cancer. JAMA. 2009; 301:2553-2562.

152. Rahbari NN, Bork U, Hinz U, Leo A, Kirchberg J, Koch M, Büchler MW, Weitz J. AB0 blood group and prognosis in patients with pancreatic cancer. BMC Cancer. 2012; 12:319-328.

153. Qi L, Cornelis MC, Kraft P, Jensen M, van Dam RM, Sun Q, Girman CJ, Laurie CC, Mirel DB, Hunter DJ, Rimm E, Hu FB. Genetic variants in ABO blood group region, plasma soluble E-selectin levels and risk of type 2 diabetes. Hum Mol Genet. 2010; 19:1856-1862.

154. Wu L, Rabe KG, Petersen GM. Do variants associated with susceptibility to pancreatic cancer and type 2 diabetes reciprocally affect risk? PLoS One. 2015; 10:e0117230.

155. Weiss FU, Schurmann C, Teumer A, Mayerle J, Simon P, Völzke H, Greinacher A, Kuehn JP, Zenker M, Völker U, Homuth G, Lerch MM. ABO blood type B and fucosyltransferase 2 non-secretor status as genetic risk factors for chronic pancreatitis. Gut. 2016; 65:353-354.

156. Kirby A, Gnirke A, Jaffe DB, Barešová V, Pochet N, Blumenstiel B, Ye C, Aird D, Stevens C, Robinson JT, Cabili MN, Gat-Viks I, Kelliher E, et al. Mutations causing medullary cystic kidney disease type 1 (MCKD1) lie in a large VNTR in MUC1 missed by massively parallel sequencing. Nat Genet. 2013; 45:299-303.

157. Martinez E, Silvy F, Fina F, Bartoli M, Krahn M, Barlesi F, Figarella-Branger D, Iovanna J, Laugier R, Ouaissi M, Lombardo D, Mas E. Rs488087 single nucleotide polymorphism as predictive risk factor for pancreatic cancers. Oncotarget. 2015; 6:39855-39864. https://doi. org/10.18632/oncotarget.5627.

158. Martinez E, Silvy F, Lombardo D, Mas E. Single nucleotide polymorphisms as risk factors predictive of pancreatic adenocarcinoma. Cancer Cell \& Microenvironment. 2016; 3:e1231.

159. Kawesha A, Ghaneh P, Andrén-Sandberg A, Ograed D, Skar R, Dawiskiba S, Evans JD, Campbell F, Lemoine $\mathrm{N}$, Neoptolemos JP. K-ras oncogene subtype mutations are associated with survival but not expression of $\mathrm{p} 53$, p16(INK4A), p21(WAF-1), cyclin D1, erbB-2 and erbB-3 in resected pancreatic ductal adenocarcinoma. Int J Cancer. 2000; 89:469-474.

160. Rachakonda PS, Bauer AS, Xie H, Campa D, Rizzato C, Canzian F, Beghelli S, Greenhalf W, Costello E, Schanne M, Heller A, Scarpa A, Neoptolemos JP, et al. Somatic mutations in exocrine pancreatic tumors: association with patient survival. PLoS One. 2012; 8:e60870.

161. Miglio U, Oldani A, Mezzapelle R, Veggiani C, Paganotti A, Garavoglia M, Boldorini R. KRAS mutational analysis in ductal adenocarcinoma of the pancreas and its clinical significance. Pathol Res Pract. 2014; 210:307-311.

162. Dalva M, El Jellas K, Steine SJ, Johansson BB, Ringdal M, Torsvik J, Immervoll H, Hoem D, Laemmerhirt F, Simon P, Lerch MM, Johansson S, Njølstad PR, et al. Copy number variants and VNTR length polymorphisms of the carboxylester lipase (CEL) gene as risk factors in pancreatic cancer. Pancreatology. 2017; 17:83-88.

163. Martinez E, Crenon I, Silvy F, Del Grande J, Mougel A, Barea D, Fina F, Bernard JP, Ouaissi M, Lombardo D, Mas E. Expression of truncated bile salt-dependent lipase variant in pancreatic pre-neoplastic lesions. Oncotarget. 2017; 8:536-551. https://doi.org/10.18632/oncotarget.11777.

164. Tian C, Kosoy R, Nassir R, Lee A, Villoslada P, Klareskog L, Hammarström L, Garchon HJ, Pulver AE, Ransom M, Gregersen PK, Seldin MF. European population genetic substructure: further definition of ancestry informative markers for distinguishing among diverse European ethnic groups. Mol Med. 2009; 15:371-383.

165. Seldin MF, Shigeta R, Villoslada P, Selmi C, Tuomilehto J, Silva G, Belmont JW, Klareskog L, Gregersen PK. European population substructure: clustering of northern and southern populations. PLoS Genet. 2006; 2: e143.

166. Escribano MJ, Imperial S. Purification and molecular characterization of FAP, a feto-acinar protein associated with the differentiation of human pancreas. J Biol Chem. 1989; 264:21865-21871.

167. Escribano MJ, Cordier J, Nap M, Ten Kate FJ, Burtin P. Differentiation antigens in fetal human pancreas. Reexpression in cancer. Int J Cancer. 1986; 38:155-160.

168. Albers GH, Escribano MJ, Gonzalez M, Mulliez N, Nap M. Fetoacinar pancreatic protein in the developing human pancreas. Differentiation. 1987; 34:210-215. 
169. Mas E, Abouakil N, Roudani S, Miralles F, Guy-Crotte O, Figarella C, Escribano MJ, Lombardo D. Human fetoacinar pancreatic protein: an oncofetal glycoform of the normally secreted pancreatic bile-salt-dependent lipase. Biochem J. 1993; 289:609-615.

170. Pasqualini E, Caillol N, Panicot L, Mas E, Lloubes R, Lombardo D. Molecular cloning of the oncofetal isoform of the human pancreatic bile salt-dependent lipase. J Biol Chem. 1998; 273:28208-28218.

171. Mas E, Crotte C, Lecestre D, Michalski JC, Escribano MJ, Lombardo D, Sadoulet MO. The oncofetal J28 epitope involves fucosylated O-linked oligosaccharide structures of the fetoacinar pancreatic protein. Glycobiology. 1997; 7:745-752.

172. Franceschi C, Collignon A, Isnardon D, Benkoel L, Vérine A, Silvy F, Bernard JP, Lombardo D, Beraud E, Olive D, Mas E. A novel tumor-associated pancreatic glycoprotein is internalized by human dendritic cells and induces their maturation. J Immunol. 2011; 186:4067-4077.

173. Béraud E, Collignon A, Franceschi C, Olive D, Lombardo $\mathrm{D}$, Mas E. Investigation of a new tumor-associated glycosylated antigen as target for dendritic cell vaccination in pancreatic cancer. Oncoimmunology. 2012; 1:56-61.

174. Miralles F, Langa F, Mazo A, Escribano MJ. Retention of the fetoacinar pancreatic (FAP) protein to the endoplasmic reticulum of tumor cells. Eur J Cell Biol. 1993; 60:115-121.

175. Mas E, Pasqualini E, Caillol N, El Battari A, Crotte C, Lombardo D, Sadoulet MO. Fucosyltransferase activities in human pancreatic tissue: comparative study between cancer tissues and established tumoral cell lines. Glycobiology. 1998; 8:605-613.

176. Panicot L, Mas E, Pasqualini E, Zerfaoui M, Lombardo D, Sadoulet MO, El Battari A. The formation of the oncofetal J28 glycotope involves core-2 beta6N-acetylglucosaminyltransferase and alpha3/4fucosyltransferase activities. Glycobiology. 1999; 9:935-946.

177. Colley KJ. Golgi localization of glycosyltransferases: more questions than answers. Glycobiology. 1997; 7:1-13.

178. Collignon A, Perles-Barbacaru AT, Robert S, Silvy F, Martinez E, Crenon I, Germain S, Garcia S, Viola A, Lombardo D, Mas E, Béraud E. A pancreatic tumorspecific biomarker characterized in humans and mice as an immunogenic onco-glycoprotein is efficient in dendritic cell vaccination. Oncotarget. 2015; 6:23462-23479. https://doi. org/10.18632/oncotarget.4359.

179. Benkoël L, Bernard JP, Payan-Defais MJ, Crescence L, Franceschi C, Delmas M, Ouaissi M, Sastre B, Sahel J, Benoliel AM, Bongrand P, Silvy F, Gauthier L, et al. Monoclonal antibody 16D10 to the COOH-terminal domain of the feto-acinar pancreatic protein targets pancreatic neoplastic tissues. Mol Cancer Ther. 2009; 8:282-291.

180. Panicot-Dubois L, Aubert M, Franceschi C, Mas E, Silvy F, Crotte C, Bernard JP, Lombardo D, Sadoulet MO. Monoclonal antibody $16 \mathrm{D} 10$ to the C-terminal domain of the feto-acinar pancreatic protein binds to membrane of human pancreatic tumoral SOJ-6 cells and inhibits the growth of tumor xenografts. Neoplasia. 2004; 6:713-724.

181. Crescence L, Beraud E, Sbarra V, Bernard JP, Lombardo D, Mas E. Targeting a novel onco-glycoprotein antigen at tumoral pancreatic cell surface by mAb16D10 induces cell death. J Immunol. 2012; 189:3386-3396.

182. El Jellas K, Immervoll H, Steffensen O, Johansson BB, Fjeld K, Lombardo D, Njolstad PR, Mas E, Molven A. Carboxyl-ester lipase (CEL) as biomarker in pancreas cancer: characterization of the monoclonal antibody 16D10 targeting pancreatic neoplastic cells and cross-reacting with histo-blood group A antigens. Pancreatology. 2015; 15:S34.

183. Li X, Sun L, Hou J, Gui M, Ying J, Zhao H, Lv N, Meng S. Cell membrane gp96 facilitates HER2 dimerization and serves as a novel target in breast cancer. Int J Cancer. 2015; 137:512-524.

184. Mollinedo F, Gajate C. Lipid rafts as major platforms for signaling regulation in cancer. Adv Biol Regul. 2015; 57:130-146.

185. Thomas GM, Panicot-Dubois L, Lacroix R, DignatGeorge F, Lombardo D, Dubois C. Cancer cell-derived microparticles bearing P-selectin glycoprotein ligand 1 accelerate thrombus formation in vivo. J Exp Med. 2009; 206:1913-1927.

186. Kerr BA, McCabe NP, Feng W, Byzova TV. Platelets govern pre-metastatic tumor communication to bone. Oncogene. 2013; 32:4319-4324.

187. Guillaumond F, Bidaut G, Ouaissi M, Servais S, Gouirand V, Olivares O, Lac S, Borge L, Roques J, Gayet O, Pinault M, Guimaraes C, Nigri J, et al. Cholesterol uptake disruption, in association with chemotherapy, is a promising combined metabolic therapy for pancreatic adenocarcinoma. Proc Natl Acad Sci USA. 2015; 112:2473-8247.

188. Ristorcelli E, Beraud E, Verrando P, Villard C, Lafitte D, Sbarra V, Lombardo D, Verine A. Human tumor nanoparticles induce apoptosis of pancreatic cancer cells. FASEB J. 2008; 22:3358-3369.

189. Beloribi-Djefaflia S, Vasseur S, Guillaumond F. Lipid metabolic reprogramming in cancer cells. Oncogenesis. 2016; 5: e189.

190. Lambert M, Ploquin A, Declerck L, Duhamel A, Makhloufi S, Turpin A, Truant S, Hebbar M. Deep Vein Thrombosis: An Independent Poor Prognosis Factor of Advanced Pancreatic Adenocarcinoma. Anticancer Res. 2016; 36:5527-5530.

191. Voigtlaender M, Holstein K, Leuenroth S, Mudter J, Bokemeyer C, Langer F. Clinical Evidence that Coagulation Activation Drives Cancer Progression-a Report of 2 Cases. Oncol Res Treat. 2015; 38:449-452.

192. Rebaï O, Le Petit-Thevenin J, Bruneau N, Lombardo D, Vérine A. In vitro angiogenic effects of pancreatic bile saltdependent lipase. Arterioscler Thromb Vasc Biol. 2005; 25:359-364.

193. Brodt-Eppley J, White P, Jenkins S, Hui DY. Plasma cholesterol esterase level is a determinant for an atherogenic 
lipoprotein profile in normolipidemic human subjects. Biochim Biophys Acta. 1995; 1272:69-72.

194. Bengtsson-Ellmark SH, Nilsson J, Orho-Melander M, Dahlenborg K, Groop L, Bjursell G. Association between a polymorphism in the carboxyl ester lipase gene and serum cholesterol profile. Eur J Hum Genet. 2004; 12:627-632.

195. Oliver MF, Geizerova H, Cumming RA, Heady JA. Serumcholesterol and $\mathrm{ABO}$ and rhesus blood-groups. Lancet. 1969; 2:605-606.

196. Klop B, van de Geijn GJ, Bovenberg SA, van der Meulen N, Elte JW, Birnie E, Njo TL, Janssen HW, van Miltenburg A, Jukema JW, Cabezas MC. Erythrocyte-Bound Apolipoprotein B in Relation to Atherosclerosis, Serum Lipids and ABO Blood Group. PLoS One. 2013; 8:e75573.

197. Aleman-Gomez JA, Colwell NS, Vyas K, Borecki I, Shonfeld G, Lange LG, Kumar VB. Relationship of human pancreatic cholesterol esterase gene structure with lipid phenotypes. Life Sci. 1999; 64:2419-2427.

198. Little JL, Wheeler FB, Fels DR, Koumenis C, Kridel SJ. Inhibition of fatty acid synthase induces endoplasmic reticulum stress in tumor cells. Cancer Res. 2007; 67:12621269.

199. Jaishy B, Abel ED. Lipids, lysosomes, and autophagy. J Lipid Res. 2016; 57:1619-1635.

200. Xu Z, Zhai L, Yi T, Gao H, Fan F, Li Y, Wang Y, Li N, Xing X, Su N, Wu F, Chang L, Chen X, et al. Hepatitis $\mathrm{B}$ virus $\mathrm{X}$ induces inflammation and cancer in mice liver through dysregulation of cytoskeletal remodeling and lipid metabolism. Oncotarget. 2016; 7:70559-70574. https://doi. org/10.18632/oncotarget.12372.

201. Le Petit-Thevenin J, Pasqualini E, Nobili O, Vérine A, Lombardo D. Effects of ethanol on the expression and secretion of bile salt-dependent lipase by pancreatic AR42J cells. Biochim Biophys Acta. 1998; 1408:44-54.

202. Le Petit-Thevenin J, Bruneau N, Nobili O, Lombardo D, Vérine A. An intracellular role for pancreatic bile saltdependent lipase : evidence for modification of lipid turnover in transfected $\mathrm{CHO}$ cells. Biochim Biophys Acta. 1998; 1393:307-316.

203. Kolar MJ, Kamat SS, Parsons WH, Homan EA, Maher T, Peroni OD, Syed I, Fjeld K, Molven A, Kahn BB, Cravatt BF, Saghatelian A. Branched Fatty Acid Esters of Hydroxy Fatty Acids Are Preferred Substrates of the MODY8 Protein Carboxyl Ester Lipase. Biochemistry. 2016; 55:4636-4641.
204. de Souza Bastos A, Graves DT, de Melo Loureiro AP, Júnior CR, Corbi SC, Frizzera F, Scarel-Caminaga RM, Câmara NO, Andriankaja OM, Hiyane MI, Orrico SR. Diabetes and increased lipid peroxidation are associated with systemic inflammation even in well-controlled patients. J Diabetes Complications. 2016; 30:1593-1599.

205. Yore MM, Syed I, Moraes-Vieira PM, Zhang T, Herman MA, Homan EA, Patel RT, Lee J, Chen S, Peroni OD, Dhaneshwar AS, Hammarstedt A, Smith U, et al. Discovery of a class of endogenous mammalian lipids with anti-diabetic and anti-inflammatory effects. Cell. 2014; 159:318-332.

206. Rebours V, Gaujoux S, d'Assignies G, Sauvanet A, Ruszniewski P, Lévy P, Paradis V, Bedossa P, Couvelard A. Obesity and Fatty Pancreatic Infiltration Are Risk Factors for Pancreatic Precancerous Lesions (PanIN). Clin Cancer Res. 2015; 21:3522-3528.

207. Swierczynski J, Hebanowska A, Sledzinski T. Role of abnormal lipid metabolism in development, progression, diagnosis and therapy of pancreatic cancer. World J Gastroenterol. 2014; 20:2279-2303.

208. Pesic M, Greten FR. Inflammation and cancer: tissue regeneration gone away. Curr Opin Cell Biol. 2016; 43:55-61.

209. Kimbara S, Kondo S. Immune checkpoint and inflammation as therapeutic targets in pancreatic carcinoma. World $\mathrm{J}$ Gastroenterol. 2016; 22:7440-7452.

210. Bian Y, Yu Y, Wang S, Li L. Up-regulation of fatty acid synthase induced by EGFR/ERK activation promotes tumor growth in pancreatic cancer. Biochem Biophys Res Commun. 2015; 463:612-617.

211. Porporato PE. Understanding cachexia as a cancer metabolism syndrome. Oncogenesis. 2016; 5:e200.

212. Bachovchin DA, Ji T, Li W, Simon GM, Blankman JL, Adibekian A, Hoover H, Niessen S, Cravatt BF. Superfamily-wide portrait of serine hydrolase inhibition achieved by library-versus-library screening. Proc Natl Acad Sci USA. 2010; 107:20941-20946.

213. Fourneron JD, Abouakil N, Chaillan C, Lombardo D. $\mathrm{N}$-Butyl-N-methyl-4-nitrophenyl carbamate as a specific active site titrator of bile-salt-dependent lipases. Eur J Biochem. 1991; 196:295-303. 